\title{
Differentiation and Functional Incorporation of Embryonic Stem Cell-Derived GABAergic Interneurons in the Dentate Gyrus of Mice with Temporal Lobe Epilepsy
}

\author{
Xu Maisano, Elizabeth Litvina, Stephanie Tagliatela, Gloster B. Aaron, Laura B. Grabel, and Janice R. Naegele \\ Department of Biology, Program in Neuroscience and Behavior, Wesleyan University, Middletown, Connecticut 06459
}

Cell therapies for neurological disorders require an extensive knowledge of disease-associated neuropathology and procedures for generating neurons for transplantation. In many patients with severe acquired temporal lobe epilepsy (TLE), the dentate gyrus exhibits sclerosis and GABAergic interneuron degeneration. Mounting evidence suggests that therapeutic benefits can be obtained by transplanting fetal GABAergic progenitors into the dentate gyrus in rodents with TLE, but the scarcity of human fetal cells limits applicability in patient populations. In contrast, virtually limitless quantities of neural progenitors can be obtained from embryonic stem (ES) cells. ES cell-based therapies for neurological repair in TLE require evidence that the transplanted neurons integrate functionally and replace cell types that degenerate. To address these issues, we transplanted mouse ES cell-derived neural progenitors (ESNPs) with ventral forebrain identities into the hilus of the dentate gyrus of mice with TLE and evaluated graft differentiation, mossy fiber sprouting, cellular morphology, and electrophysiological properties of the transplanted neurons. In addition, we compared electrophysiological properties of the transplanted neurons with endogenous hilar interneurons in mice without TLE. The majority of transplanted ESNPs differentiated into GABAergic interneuron subtypes expressing calcium-binding proteins parvalbumin, calbindin, or calretinin. Global suppression of mossy fiber sprouting was not observed; however, ESNP-derived neurons formed dense axonal arborizations in the inner molecular layer and throughout the hilus. Whole-cell hippocampal slice electrophysiological recordings and morphological analyses of the transplanted neurons identified five basic types; most with strong after-hyperpolarizations and smooth or sparsely spiny dendritic morphologies resembling endogenous hippocampal interneurons. Moreover, intracellular recordings of spontaneous EPSCs indicated that the new cells functionally integrate into epileptic hippocampal circuitry.

\section{Introduction}

Temporal lobe epilepsy (TLE) with pharmacoresistant seizures is linked to neurodegeneration, altered ion channel expression, and neuroplasticity. Two hallmarks of severe TLE are hippocampal sclerosis (Margerison and Corsellis, 1966; Swartz et al., 2006) and GABAergic interneuron loss (de Lanerolle et al., 1989; Robbins et al., 1991; Obenaus et al., 1993; Houser and Esclapez, 1996; Zhang et al., 2009). In the hilus, somatostatin (SOM)-expressing GABAergic interneurons account for $\sim 80 \%$ of the degenerating hippocampal

Received May 30, 2011; revised,; accepted 0ct. 27, 2011.

Author contributions: X.M., E.L., G.B.A., and J.R.N. designed research; X.M., E.L., S.T., and J.R.N. performed research; L.B.G. contributed unpublished reagents/analytic tools; X.M., E.L., S.T., G.B.A., L.B.G., and J.R.N. analyzed data; X.M., S.T., G.B.A., L.B.G., and J.R.N. wrote the paper.

This work was supported by the Connecticut Stem Cell Initiative (J.R.N., L.B.G., G.B.A.), a McKnight Foundation Neuroscience of Brain Disorders Award (J.R.N.), and National Institutes of Health Grant R01 NS42826 (J.R.N.). We thank Sara Royston, Noelle Germain, and Erin Banda for technical assistance with the experiments; Paul J. Lombroso and David Maisano for helpful comments on this manuscript; Ralph DiLeone and Jaime Maldonado for probes and protocols for fluorescence in situ hybridization protocol; and Angela Lentini, Sera Brown, and Peter Shatos for animal care.

Correspondence should be addressed to Janice R. Naegele at the above address. E-mail: jnaegele@wesleyan.edu.

X. Maisano's present address: Department of Genetics and Developmental Biology, University of Connecticut Health Center, 400 Farmington Avenue, Farmington, СT 06030.

E. Litvina's present address: Department of Neurobiology, Harvard Medical School, 220 Longwood Avenue, Boston, MA 02115.

DOI:10.1523/JNEUROSCI.2683-11.2012

Copyright $\odot 2012$ the authors $\quad 0270-6474 / 12 / 320046-16 \$ 15.00 / 0$ interneurons in rodents with severe TLE (Buckmaster and JongenRêlo, 1999). In addition, many calretinin (CR)-expressing neurons die (Tóth et al., 2010). In contrast, calbindin (CB)- and parvalbumin $(\mathrm{PV})$-expressing interneurons are seizure resistant and undergo hypertrophy, possibly as a compensatory response (Wittner et al., 2002; Thind et al., 2010). Mossy fiber sprouting in the dentate gyrus is an additional phenomenon that may contribute to hyperexcitability.

Neural progenitors from the fetal brain are a potential cell source for replacing interneurons in patients with severe drugrefractory TLE (Naegele et al., 2010). For instance, human fetal neural stem cells were shown to provide rapid trophic support for injured neurons by forming gap junctions (Jäderstad et al., 2010). Additionally, when fetus-derived GABAergic progenitors from the medial ganglionic eminence (MGE) were transplanted into the cerebral cortex of transgenic mice with an inherited form of epilepsy, they increased inhibitory post-synaptic currents and successfully reduced the frequency and severity of seizures (Xu et al., 2004; Alvarez-Dolado et al., 2006; Baraban et al., 2009). Moreover, when transplanted into adult rodents with TLE, fetal MGE cells reduced inflammation (Waldau et al., 2010) and lowered seizure susceptibility (Calcagnotto et al., 2010).

Despite these promising findings, the restricted availability of human fetal tissue poses a significant limitation for developing therapeutic treatments for intractable epilepsy. However, abundant supplies of neural progenitors can now be generated from 
embryonic stem (ES) cells (Kim and de Vellis, 2009; Maisano et al., 2009). In vitro genesis of ES cell-derived neural precursors (ESNPs) specified with ventral forebrain cell fates is possible by cultivating the cells with sonic hedgehog, growth factors, and signaling molecules that inhibit the Wnt pathway (Barberi et al., 2003; Watanabe et al., 2005; Aubry et al., 2008; Li et al., 2009). Additional enhancements, such as genetic modification of ESNPs with fluorescent reporter constructs, have made it possible to enrich populations of ESNPs from pluripotent ES cell cultures using fluorescence-activated cell sorting (Maroof et al., 2010).

Several studies have established that mixed populations of ESNPs can functionally integrate into epileptic brain tissue after transplantation into the hippocampus (Wernig et al., 2004; Ruschenschmidt et al., 2005). However, it is not yet known whether ESNPs are suitable for replacing GABAergic interneurons in the adult hippocampus of rodents with spontaneous recurrent seizures. To address this question, we made bilateral GABAergic progenitor-enriched ESNP transplants into the hilus of the dentate gyrus of adult mice with pilocarpine-induced TLE. Two to three months after transplantation, substantial numbers of the ESNP-derived GABAergic interneurons were identified in the hilus, with extensive axonal projections throughout the dentate gyrus. Whole-cell electrophysiological recordings and biocytin staining of the transplanted cells demonstrated functional subtypes of neurons resembling endogenous hilar interneurons.

\section{Materials and Methods}

Derivation of ES-derived neural progenitors. The two cell lines used for generating ESNPs were the Sox1-GFP/ubiquitin RFP ES cell line (Germain et al., 2011) and the parental Sox1-GFP ES line (Ying and Smith, 2003). The Sox1-GFP/ubiquitin RFP ESNPs were used for transplants. GFP expression is transient, but the constitutive RFP expression in this cell line allowed us to identify the ES-derived cells after transplantation. Unless otherwise specified, all medium components were purchased from Sigma-Aldrich. The cells were cultured on $0.1 \%$ gelatin-coated culture dishes (Corning) in the ES medium composed of Glasgow Minimum Essential Medium containing 10\% fetal bovine serum (Atlanta Biologicals), $1 \mathrm{~mm}$ nonessential amino acids, $2 \mathrm{~mm}$ glutamine, $1 \mathrm{~mm}$ sodium pyruvate, $100 \mathrm{U} / \mathrm{ml}$ penicillin/streptomycin (Invitrogen), 0.1 mм $\beta$-mercaptoethanol, and LIF (leukemia inhibitory factor derived from CHO-LIF cells). The day of ES cell plating was designated day 0 . Pluripotent ES cells were passaged every $2 \mathrm{~d}$.

To generate neural stem cells, ES cells were trypsinized, plated as a monolayer on $0.1 \%$ gelatin-coated culture dishes (Corning) at a density of $0.5-1.5 \times 10^{4}$ cells $/ \mathrm{cm}^{2}$, and differentiated in N2B27 medium containing neural basal medium (Invitrogen) and DMEM/F-12 (1:1 ratio) supplemented with 1\% B27 (Invitrogen), $100 \mathrm{U} / \mathrm{ml}$ penicillin/streptomycin (Invitrogen), 2 mM L-glutamine, 1\% insulin-transferrin-selenite (Invitrogen), $25 \mu \mathrm{g} / \mathrm{ml} \mathrm{BSA,} 6 \mathrm{ng} / \mathrm{ml}$ progesterone, $16 \mu \mathrm{g} / \mathrm{ml}$ putrescine, and $0.1 \mathrm{~mm} \beta$-mercaptoethanol. The neural stem cells were frozen in liquid nitrogen at the stage when $\sim 80 \%$ were $\mathrm{GFP}^{+}, \sim 7 \mathrm{~d}$ after plating (day 9).

Neural stem cell differentiation into ESNPs. Neural stem cells were thawed and plated onto laminin-coated, two-well glass chamber slides (Thermo-Scientific Nunc Lab-Tek II CC2) at a density of $6 \times 10^{5}$ cells/ml and grown in N2B27 medium supplemented with $2.5 \mathrm{~nm} \mathrm{Hh}$ agonist (Cur199567; Curis) for $1 \mathrm{~d}$, to aid survival and promote ventral forebrain progenitor fates. The Hh agonist-containing medium was replaced with N2B27 for $1 \mathrm{~d}$ (on day 11), and the cells were then replated onto laminin-coated, two-well and eight-well chamber slides at a density of $3 \times 10^{5}$ cells $/ \mathrm{ml}$ in N2B27 medium containing Hh agonist for 1 additional day. The cells were grown in N2B27 for 2 additional days before harvesting on day 14 for transplantation.

$R T-P C R$ and real-time quantitative PCR analyses. To analyze the expression of transcription factors in the cultures, ESNPs or ES cells were dissociated in ultraspec-RNA (Biotecx Laboratories) and analyzed by
Table 1. Primers used for PCR analyses

\begin{tabular}{|c|c|}
\hline Gene & Sequence \\
\hline \multirow[t]{2}{*}{ Oct4 } & 5'-GGCGTTCTCTTTGGAAAGGTGTTC-3' \\
\hline & 5'-CTCGAACCACATCCTTCTCT-3' \\
\hline \multirow[t]{2}{*}{$N k x 2.1$} & 5'-AACAGCGGCCATGCAGCAGCAC-3' \\
\hline & 5' -CCATGTTCTTGCTCACGTCC-3' \\
\hline \multirow[t]{2}{*}{ Mash1 } & 5'-CTCGTCCTCTCCGGAACTGATG-3' \\
\hline & $5^{\prime}$-CGACAGGACGCCCGCCTGAAA G-3' \\
\hline \multirow[t]{2}{*}{$\operatorname{Ngn} 2$} & 5'-AGCACCGCCTCCGTGAAGAG-3' \\
\hline & 5'-ACGGTGCAGCGCATCAAGAA-3' \\
\hline \multirow[t]{2}{*}{ Pax7 } & 5'-CCAAGATTCTTTGCCGCTAC-3' \\
\hline & 5'-CAGGATGCCGTCGATGCTGT-3' \\
\hline \multirow[t]{2}{*}{ Pax6 } & 5' -GCAAACACATCTGGATAATGGG-3' \\
\hline & 5'-TGTGAGTAAAATTCTGGGCAGG-3' \\
\hline \multirow[t]{2}{*}{ Emx 1} & 5'-AGCGACGTTCCCCAGGACGGGCTGC-3' \\
\hline & 5'-CTGAGGTCACTTGGTC-3' \\
\hline \multirow[t]{2}{*}{ GAPDH } & 5'-ACCACAGTCCATGCCATCAC-3' \\
\hline & 5'-TCCACCACCCTGTTGCTGTA-3' \\
\hline
\end{tabular}

reverse transcriptase-PCR (RT-PCR) or real-time quantitative PCR (RT-qPCR). Total mRNA was extracted from the cells after plating on days 2, 9, 11, and 14. For comparison, fetal mouse MGE mRNA extracts were obtained from six CD-1 embryos at embryonic day 13.5 (Charles River). Cells were dissociated in ultraspec-RNA and incubated in Turbo DNA-free (Applied Biosystems). The mRNA concentration was measured by spectrophotometry (Nanodrop Spectrophotometer; Thermo Fisher Scientific). Reverse transcription was performed on $10 \mu \mathrm{g}$ of mRNA using the High-Capacity cDNA Reverse Transcription kit (Applied Biosystems). The primers (Integrated DNA Technologies) are shown in Table 1.

RT-qPCR analyses were performed with TaqMan primers (Applied Biosystems). The housekeeping gene glyceraldehyde-3-phosphate dehydrogenase (GAPDH; ID: Mm99999915_g1) was used as a loading control. TaqMan gene expression assays were performed for the following murine genes: microtubule-associated protein 2 (Mtap2; $91 \mathrm{bp}$, Tm_60 ${ }^{\circ} \mathrm{C}$; ID: Mm00485230_m1), glutamic acid decarboxylase 2 (Gad2; 99 bp, Tm_60 ${ }^{\circ} \mathrm{C}$, ID: Mm00484623_m1) (Chatzi et al., 2009), distal-less homeobox 2 (Dlx2; ID: Mm00438427_m1), and paired box gene 6 (Pax6; ID: Mm00443072_m1). RT-qPCR results were averaged from triplicate samples processed in parallel, and the results were replicated in three separate sets of experiments. Data analyses were performed with SDS version $1.2 \mathrm{x}$ system software (Applied Biosystems).

Immunohistochemical analyses of ES-derived neural progenitors in vitro. Cultures of ESNPs were maintained until day 14 in eight-well chamber slides, fixed at room temperature in $4 \%$ paraformaldehyde (PFA) in $0.1 \mathrm{M}$ phosphate $\left(\mathrm{PO}_{4}\right)$, rinsed in $\mathrm{PBS}, \mathrm{pH}$ 7.4, and stored in antifreeze medium consisting of $30 \%$ ethylene glycol and $30 \%$ glycerol in $0.1 \mathrm{M} \mathrm{PO}_{4}$ until immunostaining was performed. Tissue sections were permeabilized with $0.3 \%$ Triton X-100 and blocked in $0.1 \%$ Tween $20,2 \%$ BSA, and $5 \%$ normal goat serum in PBS, before staining in one or more of the following antibodies (diluted 1:1000 unless otherwise noted): mouse antinestin (Millipore Corporation), rabbit anti-phospho-histone $\mathrm{H} 3$ (Millipore Corporation), mouse anti-MAP2 (Sigma-Aldrich), mouse anti- $\beta$-3 tubulin (1:2000, BabCO), mouse anti-Mash 1 (1:500, BD), rabbit anti-Tbr 2 (Millipore Corporation), rabbit anti-CR (Millipore Corporation), and rabbit anti-CB (Swant). The staining was detected with species-appropriate secondary antibodies including goat anti-mouse IgG-Alexa 488, goat anti-mouse IgG-Alexa 647, or goat anti-rabbit IgGAlexa 568 (1:1000 dilution; Invitrogen). Controls consisted of experiments in which the primary antibodies were omitted. Because of negligible expression of Sox1-GFP in ES cell derivatives after fixation, immunodetection of nestin, MAP2, and $\beta-3$ tubulin was performed using Alexa 488-conjugated secondary antibodies. Quantification of cellular expression of nestin, phospho-histone H3 (H3), MAP2, $\beta$-3 tubulin, or Mash1 was determined by calculating the percentage of cells expressing the specific molecular marker divided by total cell population; quantifications for $\mathrm{CB}$ and $\mathrm{CR}$ were determined by calculating the percentage of cells expressing the marker divided by the number of $\mathrm{MAP}^{+}{ }^{+}$cells. 
Table 2. Analysis of ESNP transplants

\begin{tabular}{lllll}
\hline Case number & $\begin{array}{l}\text { Survival } \\
\text { (days) }\end{array}$ & Graft location & $\begin{array}{l}\text { Cells characterized } \\
\text { by electrophysiology }\end{array}$ & Immunohistochemistry \\
\hline SE 011510-06 & 70 & DG and hilus & Not done & Yes \\
SE 011810-02 & 91 & DG and 0ML & Not done & Yes \\
SE 011810-04 & 91 & OML & Not done & Yes \\
SE 112309-04 & 72 & DG and hilus & $31(\mathrm{DG}), 32(\mathrm{DG})$ & Not done \\
SE 041410-01 & 81 & Hilus & $25,26,27(\mathrm{H}), 28$ & Not done \\
SE 041410-06 & 55 & OML & $1(\mathrm{H}), 2,3(\mathrm{OML})$ & Not done \\
SE 041410-07 & 76 & OML & No access & Not done \\
SE 041410-12 & 62 & CA3 & 9,10 & Not done \\
SE 041910-02 & 57 & Hilus & $5(\mathrm{H}), 6,7(\mathrm{H}), 8(\mathrm{H})$ & Yes \\
SE 041910-03 & 71 & Hilus and CA1 & $18(\mathrm{H}), 19(\mathrm{CA1}), 20,21$ & Yes \\
SE 041910-06 & 75 & OML & $22,23(0 \mathrm{ML}), 24(0 \mathrm{ML})$ & Not done \\
SE 041910-08 & 80 & OML & $29(0 \mathrm{ML}), 30$ & Not done \\
SE 041410-09 & 56 & OML & $4(0 \mathrm{ML})$ & Not done \\
SE 041910-10 & 67 & OML & $11,12(0 \mathrm{ML}), 13,14$ & Yes \\
SE 041910-12 & 68 & Hilus & $15(\mathrm{H}), 16,17$ & Yes \\
\hline
\end{tabular}

One mouse (SE 041910-04) was excluded from the study because of a tumor. Animal identification was assigned as the date of pilocarpine-induced status epilepticus. DG, Dentate gyrus granule cell layer; OML, outer molecular layer; $H$, hilus.

Pilocarpine-induced status epilepticus in mice. The Wesleyan Institutional Animal Care and Use Committee, in accordance with the Public Health Service Policy on Humane Care and Use of Laboratory Animals, approved all procedures involving animals. Six- to eight-week-old C57BL/6 adult male mice from Harlan were housed individually and handled daily for 2 weeks before experimentation. To induce seizures, the mice were given injections of $0.07 \mathrm{cc}$ of $0.5 \mathrm{mg} / \mathrm{ml}$ atropine methyl nitrate in sterile saline (i.p. Sigma-Aldrich). Thirty minutes later, the mice were given injections of pilocarpine in sterile saline $(280 \mathrm{mg} / \mathrm{kg}$, i.p.; Sigma-Aldrich). Seizures were scored by a modified Racine scale (Shibley and Smith, 2002), and status epilepticus (SE) was defined as three or more stage 5 seizures. After $1 \mathrm{~h}$ of SE, the seizures were attenuated with diazepam (10 mg/kg, i.p.; Henry Schein). The mice were given injections of sterile Ringer's solution (subcutaneously; Henry Schein) and were returned to their home cages. For this study, we induced seizures in 62 mice; 36 of them reached SE (58\%), and 21 survived (34\%) for up to 4 months. Nineteen mice died during seizure induction (30\%). Of the surviving SE mice, 16 received ESNP transplants (Table 2). The immunosuppressant cyclosporine A (100 mg/L; Calbiochem) was supplied to the mice in the drinking water beginning $2 \mathrm{~d}$ before transplantation and continued until the mice were killed.

Stem cell transplantation. Two weeks after induction of SE, adult male mice were anesthetized with isoflurane and received bilateral injections of $\sim 100,000$ cells in $1 \mu \mathrm{l}$ of N2B27 medium per hippocampus, using a digital stereotaxic apparatus (David Kopf Instruments) outfitted with a glass syringe and a 22 gauge needle with a $30^{\circ}$ bevel (Hamilton). The stereotactic coordinates for the dentate gyrus of the dorsal hippocampus were as follows: anteroposterior, $2.5 \mathrm{~mm}$; ML, $\pm 2.1 \mathrm{~mm}$; DV, $2.0 \mathrm{~mm}$. After stereotaxic injections, the needle was left in place for $5 \mathrm{~min}$ before being withdrawn. The surgical incisions were sealed using $3 \mathrm{M}$ Vetbond Tissue Adhesive (Henry Schein), and the mice were monitored during recovery in their original cages.

Perfusion and immunohistochemistry. Eight to 10 weeks after receiving ESNP grafts, one group of mice was killed to examine the phenotypes of the transplanted ESNPs. Mice were overdosed with sodium pentobarbital (200 mg/kg i.p.; Abbott Laboratories) and perfused with 4\% PFA in $0.1 \mathrm{M} \mathrm{PO}_{4}$, pH 7.4, containing $1 \mu \mathrm{g} / \mathrm{ml}$ heparin (Butler Schein Animal Health) and $10 \%$ sucrose. The brains were postfixed in $4 \%$ PFA overnight at $4^{\circ} \mathrm{C}$, equilibrated in sucrose, embedded in tissue-freezing medium (Triangle Biomedical Sciences), and stored at $-80^{\circ} \mathrm{C}$. Cryostat sections were cut at $12 \mu \mathrm{m}$ intervals in the coronal or horizontal planes, thaw mounted onto Superfrost Plus slides, and stored at $-80^{\circ} \mathrm{C}$.

For immunohistochemical analyses, cryostat sections were permeabilized in $0.3 \%$ Triton X-100 for 20 min and incubated for $1 \mathrm{~h}$ in blocking buffer containing $0.1 \%$ Tween $20,2 \%$ BSA, and $5 \%$ normal goat serum. The sections were then incubated at $4^{\circ} \mathrm{C}$ for $12-18 \mathrm{~h}$ in primary antibod- ies. The following primary antibodies were used (1:1000 dilution, unless otherwise noted): rabbit anti-RFP (Rockland Immunochemicals), rabbit anti-SOM (Bachem Biosciences), rabbit anti-PV (Sigma-Aldrich), mouse anti-NeuN (1:500; Millipore Corporation), rabbit anti-CB (Swant), mouse anti-CR (Swant), and rat anti-ctip2 (1:500; Abcam). For $\mathrm{PV}$ and SOM staining, heat-induced epitope antigen retrieval in citric acid buffer, $\mathrm{pH} 6$, was performed before permeabilization. Goat antirabbit IgG-Alexa 568 was used to detect RFP in combination with goat anti-mouse IgG-Alexa 488, goat anti-rat IgG-Alexa 488, or goat antimouse IgG Alexa-647. For PV, SOM, and CB/ctip2 staining, we omitted the rabbit anti-RFP antibody, as the unamplified fluorescent signal from the cells was sufficient for microscopic detection. Nuclear staining was performed with Hoechst 33342 (1:10,000; Invitrogen) or Sytox green (1:10,000; Invitrogen). To quantify the proportions of transplanted cells expressing different molecular markers, three brain sections containing the transplanted cells were counted from each mouse. The sections were $\sim 100 \mu \mathrm{m}$ apart, and counts were made in a minimum of four mice. Data were expressed as the percentage of cells expressing the antigen/total $\mathrm{RFP}^{+}$cells. The standard errors of the means were calculated.

Mossy fiber sprouting. Dual immunofluorescent staining of mossy fiber sprouting and transplanted ESNPs was performed in vibratome sections of the hippocampus that were fixed, cryoprotected, sectioned at $12 \mu \mathrm{m}$ thicknesses, and mounted onto slides. Antigen retrieval was performed in citric acid buffer, and endogenous peroxidase activity was quenched with $0.5 \%$ hydrogen peroxide in sodium phosphate buffer. The sections were then incubated in Tris-saline buffer containing blocking reagent (TNB; Perkin Elmer Life and Analytical Sciences) followed by incubation in primary antibody mixture consisting of rabbit anti-RFP and guinea pig anti-zinc transporter $\mathrm{T} 3\left(\mathrm{ZnT}_{3} ; 1: 200\right.$; Synaptic Systems) to label mossy fibers. Detection of the guinea pig primary antibody was performed with goat anti-guinea pig IgG conjugated to HRP (1:1000; Invitrogen). Tyramide signal amplification with green fluorescence was performed for $10 \mathrm{~min}$, according to the manufacturer's instructions (PerkinElmer Life and Analytical Sciences). Sections were then incubated at room temperature for $30 \mathrm{~min}$ in goat anti-rabbit IgG-Alexa 568 conjugate (1:500; Invitrogen), stained for Nissl substance with Neurotrace (1:200; Invitrogen), and mounted in Prolong Antifade reagent containing DAPI. Confocal images were collected on a Carl Zeiss LSM 510 laserscanning confocal microscope.

Fluorescent in situ hybridization. Immunochemical staining for GABA significantly underestimates the number of GABAergic neurons in the mouse brain (Houser and Esclapez, 1994). We performed fluorescent in situ hybridization (FISH) for GAD1 and GAD2 mRNA to obtain accurate estimates. The mice were perfused transcardially as described above, and $12-\mu \mathrm{m}$-thick cryostat sections were prepared. Antisense digoxigenin (DIG)-labeled riboprobes were generated against the 3' UTR of GAD1 and GAD2 by in vitro transcription using DIG-11-UTP labeling mix (Roche) and Sp6 polymerase (New England Biolabs). Plasmids containing templates for the two riboprobes were provided by Dr. R. DiLeone (Yale School of Medicine, New Haven, CT).

FISH was performed by dehydrating sections in alcohols and airdrying them. The sections were then acetylated for $10 \mathrm{~min}$, dehydrated a second time, and hybridized overnight at $60^{\circ} \mathrm{C}$ with $200 \mathrm{ng}$ of antisense riboprobe in hybridization buffer. The riboprobes were denatured at $80^{\circ} \mathrm{C}$ for $5 \mathrm{~min}$ and briefly cooled on ice before hybridization. After hybridization, the sections were washed in $5 \times \mathrm{SSC}$ buffer at $65^{\circ} \mathrm{C}$ for 30 min and in $50 \%$ formamide in $2 \times$ SSC for $50 \mathrm{~min}$ at $65^{\circ} \mathrm{C}$. Sections were then treated with $2 \times, 0.2 \times$, and $0.1 \times$ SSC for $5 \mathrm{~min}$ each at room temperature, blocked in 5\% normal mouse serum (Jackson ImmunoResearch Laboratories) for $30 \mathrm{~min}$, and incubated in HRP-conjugated mouse anti-DIG antibody (1:400; Jackson ImmunoResearch Laboratories). Sections were then rinsed with TBST and incubated in fluoresceincoupled tyramide amplification reagents (PerkinElmer Life and Analytical Sciences), according to the manufacturer's instructions. Sections containing transplants were then processed for RFP expression by immunofluorescent staining, as described above, and nuclei were stained with Hoechst 33342. Controls included hybridization with sense probes for $G A D 1 / 2$. 
Hippocampal slice electrophysiology. Whole-cell patch-clamp recordings were made in hippocampal slices $8-12$ weeks after transplantation. The slices were obtained from 12 adult C57BL/6J mice 16-22 weeks of age. Additional recordings were made from hippocampal slices obtained from adult GFP-expressing inhibitory neuron (GIN) mice (Oliva et al., 2000). GFP in these mice colocalizes with SOM but not PV. The mice were decapitated under deep anesthesia induced by injection of ketamine/xylazine $(120 \mathrm{mg} / \mathrm{kg}$ ketamine plus $10 \mathrm{mg} / \mathrm{kg}$ xylazine, i.p.; Henry Schein). Brains were removed rapidly and transferred to cold, oxygenated artificial CSF (ACSF; with high sucrose, $27.07 \mathrm{~mm} \mathrm{NaHCO}_{3}, 1.5 \mathrm{~mm}$ $\mathrm{NaH}_{2} \mathrm{PO}_{4}, 1 \mathrm{~mm} \mathrm{CaCl} 2,3 \mathrm{~mm} \mathrm{MgSO}$, $2.5 \mathrm{~mm} \mathrm{KCl}, 222.14$ mm sucrose), and $350-\mu \mathrm{m}$-thick slices containing the hippocampus were cut on a Vibratome (VT1000S; Leica) in the coronal or horizontal plane at a $12.5^{\circ}$ angle, descending toward the posterior (Rafiq et al., 1993).

Electrophysiology. Slices were transferred to a chamber containing prewarmed ACSF (in mu: $125 \mathrm{NaCl}, 1 \mathrm{CaCl}, 3 \mathrm{MgSO}_{4}, 1.25 \mathrm{NaH}_{2} \mathrm{PO}_{4}, 25$ $\mathrm{NaHCO}_{3}, 25$ glucose, 3 myo-inositol, 2 Na-pyruvate, 0.4 ascorbic acid), incubated for $1 \mathrm{~h}$, and placed in the recording chamber. While recording, the slices were perfused with ACSF containing low-divalent ions (ACSF, $1.25 \mathrm{~mm} \mathrm{NaH}_{2} \mathrm{PO}_{4}, 125 \mathrm{~mm} \mathrm{NaCl}, 25 \mathrm{~mm} \mathrm{NaHCO}, 2.5 \mathrm{~mm} \mathrm{KCl}, 25 \mathrm{~mm}$ glucose, $3 \mathrm{~mm}$ myo-inositol, $2 \mathrm{~mm}$ sodium pyruvate, $0.4 \mathrm{~mm}$ ascorbic acid, $1 \mathrm{~mm} \mathrm{CaCl}_{2}, 3 \mathrm{~mm} \mathrm{MgSO}_{4}$ ) and recorded at a temperature of $34^{\circ} \mathrm{C}$.

Patch pipettes were pulled (model P-97; Sutter Instrument Company) with 6-9 M $\Omega$ resistance and filled with a solution containing $130 \mathrm{~mm}$ potassium-methylsulfonate, $11 \mathrm{~mm}$ biocytin, $10 \mathrm{~mm}$ potassium chloride, $10 \mathrm{~mm}$ HEPES, $5 \mathrm{~mm}$ sodium chloride, $2.5 \mathrm{~mm}$ Mg-ATP, $0.3 \mathrm{~mm} \mathrm{Na}$ GTP, and $0.5 \%$ mm biocytin. Analog signals were digitized at $10 \mathrm{kHz}$ with an ITC-18 (InstruTECH Corporation) and acquired with IGOR software (Wavemetrics). Passive membrane properties and firing properties of the cells were analyzed off-line with IGOR software. We measured the action potential (AP) amplitude, half-width, and delay to spike (defined as the time from the onset of stimulation to the initiation of the first AP). Spike frequency adaptation was calculated as the interval between the last two APs divided by the interval between the first two APs (McGarry et al., 2010). Voltage sag ratio was calculated as the peak voltage drop against end-voltage change in response to negative current injections of $500 \mathrm{~ms}$ durations (Haghdoust et al., 2007). The AP drop (a measure of spike accommodation) was obtained by subtracting the peak amplitude of the second AP from the first AP peak amplitude (McGarry et al., 2010). The maximum number of APs was counted in response to $80-120 \mathrm{pA}$ stimulations lasting $500 \mathrm{~ms}$. Firing frequency (in hertz) was calculated as the number of spikes evoked during the current injection divided by the duration of the spiking period, where the spiking period was defined as the time from the beginning of the current injection to the end of the last action potential evoked during the current injection. Immediately after the recordings were made, the slices were fixed in $4 \% \mathrm{PFA}$ in $0.1 \mathrm{M} \mathrm{PO}_{4}$ overnight and equilibrated in $30 \%$ sucrose for several hours before transferring to antifreeze medium for long-term storage in a $-20^{\circ} \mathrm{C}$ freezer. Some of these slices were sectioned into $12 \mu \mathrm{m}$ cryostat sections for immunohistochemical analyses (Table 2).

Biocytin staining. All procedures were performed at room temperature. Brain slices were thawed, rinsed in PBS, and incubated in PBS containing $0.02 \mathrm{M}$ potassium (KPBS) for $15 \mathrm{~min}$ before overnight incubation in a Texas Red avidin D solution consisting of $2.5 \mathrm{mg} / \mathrm{ml}$ Texas Red (Vector Laboratories) and $0.3 \%$ Triton X-100 in 0.02 м KPBS. The next day, the slices were rinsed and mounted in Prolong Antifade reagent (Invitrogen) or VectaShield (Vector Laboratories), and biocytin staining was visualized under epifluorescence with a Zeiss LSM 510 confocal laser-scanning microscope.

Statistical analyses. For comparisons of relative gene expression profiles and current-clamp recordings of different neuronal types, we performed ANOVA with Tukey's post hoc analysis in SPSS software (IBM SPSS statistics 19; SPSS). For analysis of voltage-clamp recordings, we used Matlab software (Mathworks).

\section{Results}

Generating neural progenitors from ES cells

Sox1-GFP/ubiquitin-RFP or Sox1-GFP mouse ES cells were differentiated into ESNPs in an adhesive monolayer cell-culture sys- tem (Ying and Smith, 2003; Cai et al., 2008). Sox1 is expressed by early mouse neuroectoderm and neural stem cells. In the Sox1GFP ES cell line, the expression of GFP allowed us to monitor the ES cells as they differentiated toward neural lineages (Ying and Smith, 2003). We used two steps to generate neural progenitors. Batches of ES cell-derived neural stem cells were frozen down in liquid nitrogen, 7-9 d after transfer to neural differentiation medium when $>80 \%$ expressed GFP (day 9; Fig. $1 A, D$ ). The cells were subsequently thawed and replated to further enrich the population of GFP-expressing neural progenitors to $~ 100 \%$ by approximately day 14 (Fig. $1 C-F$ ). Hh agonist was used the day of replating to enhance survival (Cai and Grabel, 2007), and many cells adopted a bipolar morphology. At this stage, nestin ${ }^{+}$ESNPs comprised $60.9 \pm 6.6 \%(n=6)$ of the total cells. A small subset $(2.1 \pm 0.4 \% ; n=5)$ of the cells was proliferative, based on $\mathrm{H} 3$ expression. Neurons at early stages were MAP2abc ${ }^{+}(29.2 \pm$ $5.9 \% ; n=6)$ or $\beta-3$ tubulin $^{+}(30 \pm 9.8 \% ; n=5)$ (Fig. $\left.1 G-I\right)$.

To characterize the regional identities of the ESNPs, we performed RT-PCR analyses at different time points after plating. Oct4, a transcription factor for pluripotency, was only strongly expressed at the ES cell stage (Fig. 2A). After replating on days 11 and 14, we detected expression of both Mash1, a marker of forebrain fate (Casarosa et al., 1999; Bertrand et al., 2002), and Nkx2.1, a marker of ventral telencephalon fate (Campbell, 2003). The dorsal forebrain transcription factors Ngn2, Pax7, and Pax6 were also expressed at this stage, but not Emx1, a transcription factor typically expressed by dorsal forebrain progenitors (data not shown) (Briata et al., 1996; Cecchi and Boncinelli, 2000).

To quantify the levels of cell-type-specific markers, RT-qPCR analyses were conducted for Map2, Pax6 (Campbell, 2003), Dlx2, and Gad2. The expression of each gene was greater at day 14 compared with earlier time points (Fig. $2 \mathrm{~B}$ ), suggesting that after the second replating, ESNPs with both ventral and dorsal forebrain fates persisted in the cultures.

To further determine the extent of differentiation of the ESNPs harvested on day 14 for transplantation, we performed quantitative immunocytochemical staining for dorsal and ventral forebrain markers. Tbr2, an early transcription factor expressed in dorsal neural progenitors fated to differentiate into excitatory projection neurons, was rarely detected (data not shown). However, $16.5 \pm 1.4 \%$ of the cells were Mash $1^{+}(n=4$; Fig. $1 \mathrm{~J}$ ), suggesting that many cells were adopting forebrain identities. To further determine the lineages of the ESNPs used for transplantation, we quantified subsets that were MAP2 ${ }^{+}$and either $\mathrm{CB}^{+}$or $\mathrm{CR}^{+}$, as subtypes of GABAergic interneurons express these calcium-binding proteins. Approximately $5.0 \pm 0.7 \%$ $(n=3)$ of the ESNPs expressed CB and $7.6 \pm 0.9 \%(n=3)$ expressed CR (Fig. $1 K, L$ ). These neuronal subtypes exhibited diverse dendritic morphologies (Fig. $1 M-R^{\prime}$ ), including some CR-expressing cells with sparse dendritic spines (Fig. $1 S, S^{\prime}$ ). Together, these results indicate that the in vitro differentiation protocol we used produced a mixture of ESNPs, including cells with ventral telencephalon identity at the time of transplantation (day 14).

\section{Differentiation of ESNPs into GABAergic interneurons within the host brain}

To evaluate incorporation and functional integration, we transplanted day 14 ESNPs into the dentate gyrus of mice with pilocarpine-induced SE (Table 2). As shown previously, SRS typically begin 2-3 weeks after an initial hour-long episode of SE induced by pilocarpine (Goffin et al., 2007). Therefore, we chose 2 weeks after SE for making the ESNP transplants. 

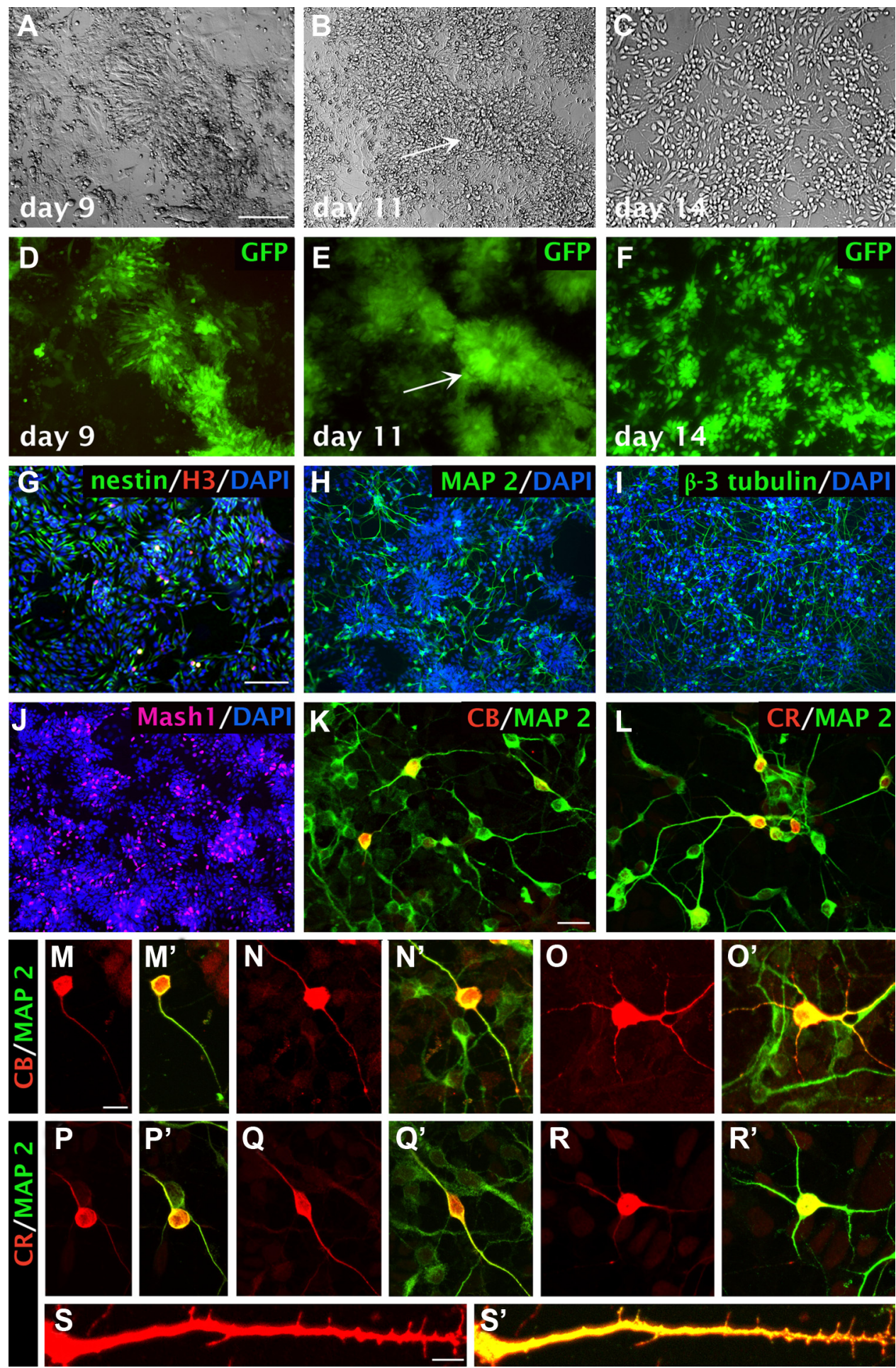

Figure 1. Time course of neuronal differentiation during derivation of neural progenitors from ES cells. $\boldsymbol{A}-\boldsymbol{F}$, Neuronal differentiation in vitro of the ES cells viewed with Nomarski optics ( $\boldsymbol{A}-\boldsymbol{C}$ ) or epifluorescence $(\boldsymbol{D}-\boldsymbol{F})$. The neural stem cell gene sox 1 drives GFP expression in this cell line, indicating commitment to neural lineages by day 9 . Distinctive neural rosettes form during the first replating step (arrows, $\boldsymbol{B}, \boldsymbol{E}) . \mathbf{G}-\boldsymbol{I}$, Day 14 neural progenitors express nestin $(\boldsymbol{G})$, MAP2 $(\boldsymbol{H})$, and neuron-specific $\beta$-3 tubulin $(\boldsymbol{I})$. Cultures also contain mitotically active cells expressing the cell cycle antigen phospho-histone H3 (G). J, Day 14 neural progenitors in the cultures also express the ventral forebrain marker Mash1 $(16.5 \pm 1.4 \%, n=4)$. $\boldsymbol{K}$, Neuronal subsets coexpress MAP2 and calbindin $(5.0 \pm 0.7 \%, \mathrm{n}=3)$ and display unipolar, bipolar, or multipolar dendritic morphology $\left(\boldsymbol{M}-\mathbf{O}^{\prime}\right)$. $\boldsymbol{L}$, Additional neurons coexpress MAP2 and calretinin $(7.6 \pm 0.9 \%, n=3)$ and exhibit a range of bipolar or multipolar dendritic morphologies $\left(\boldsymbol{P}-\boldsymbol{R}^{\prime}\right) . \boldsymbol{S}, \boldsymbol{S}^{\prime}$, Some calretinin-expressing neurons also exhibit immature dendritic spines. Scale bars: $\boldsymbol{A}-\boldsymbol{F}, 100 \mu \mathrm{m} ; \boldsymbol{G}-\boldsymbol{J}, 100 \mu \mathrm{m} ; \boldsymbol{K}, \boldsymbol{L}, \mathbf{S}, \boldsymbol{S}^{\prime}$, $20 \mu \mathrm{m} ; \boldsymbol{M}-\boldsymbol{R}^{\prime}, 10 \mu \mathrm{m}$.

We then characterized the transplanted ESNPs 2-3 months later. Postmortem immunohistochemical analyses revealed clusters of $\mathrm{RFP}^{+}$cells in the dentate gyrus granule cell layer, the hilus, or the molecular layer (Table 2), and the size of the transplants spanned $\sim 500-1500 \mu \mathrm{m}$ along the anteroposterior axis of the hippocampus. Some transplanted cells migrated into the molecular layer of the dentate gyrus, or upper blade of the granule cell layer in the dentate gyrus (Hartman et al., 2010). However, the 


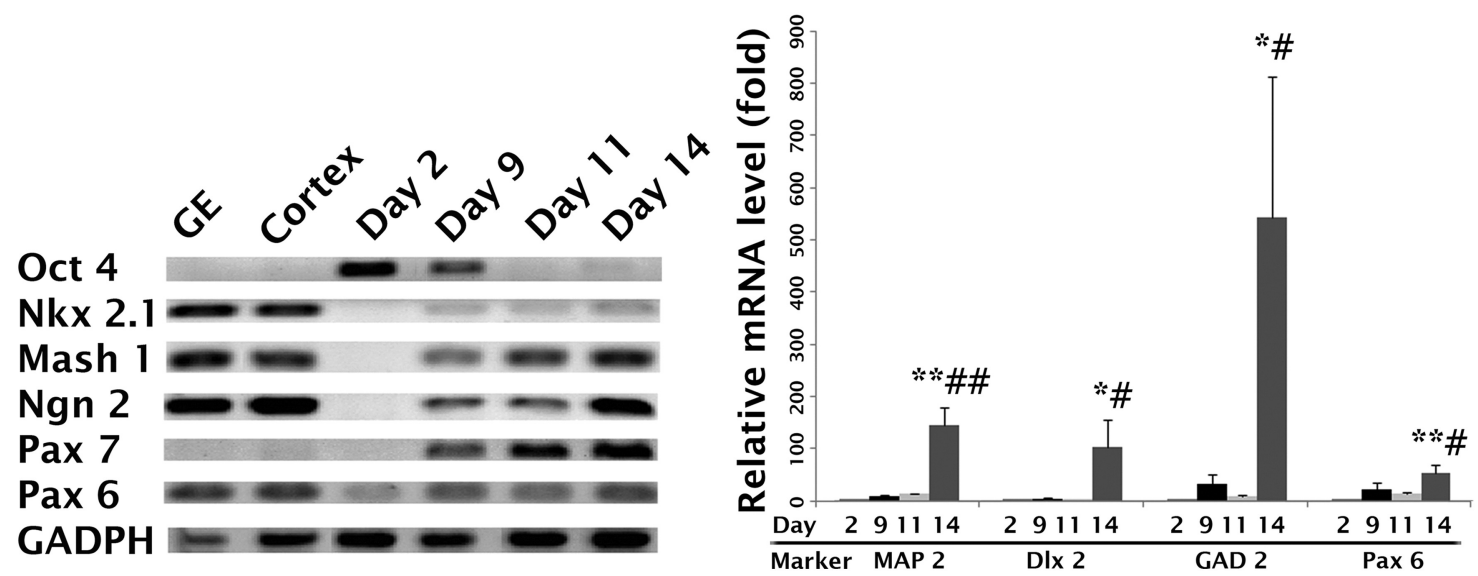

Figure 2. mRNA expression profiles for Sox1-GFP ESNPs. A, The expression of transcription factor mRNA increases from day 2 to day14, except for 0ct 4, a transcription factor expressed by pluripotent stem cells, which decreases during this period. $B$, RT-qPCR analyses of $M A P 2, D 1 \times 2, G A D 2$, and Pax6 mRNA expression at different stages of differentiation were compared with expression profiles of pluripotent ES cells on day 2. Map2 mRNA increased by 143-fold by day 14, Pax6 mRNA increased 53-fold, and D/x2 mRNA increased 103-fold. Strikingly, GAD2 mRNA increased 540-fold. Significance values were calculated by ANOVA; ${ }^{*} p<0.1$ between days 2 and $14 ; * * p<0.05$ and a significant difference comparing day 2 with day $14 ;{ }^{*} p<0.1$, significant difference comparing day 11 with day $14 ;{ }^{\# \#} p<0.05$, significant difference in expression between days 11 and 14. White, Day 2; black, day 9; light gray, day 11; dark gray, day 14.
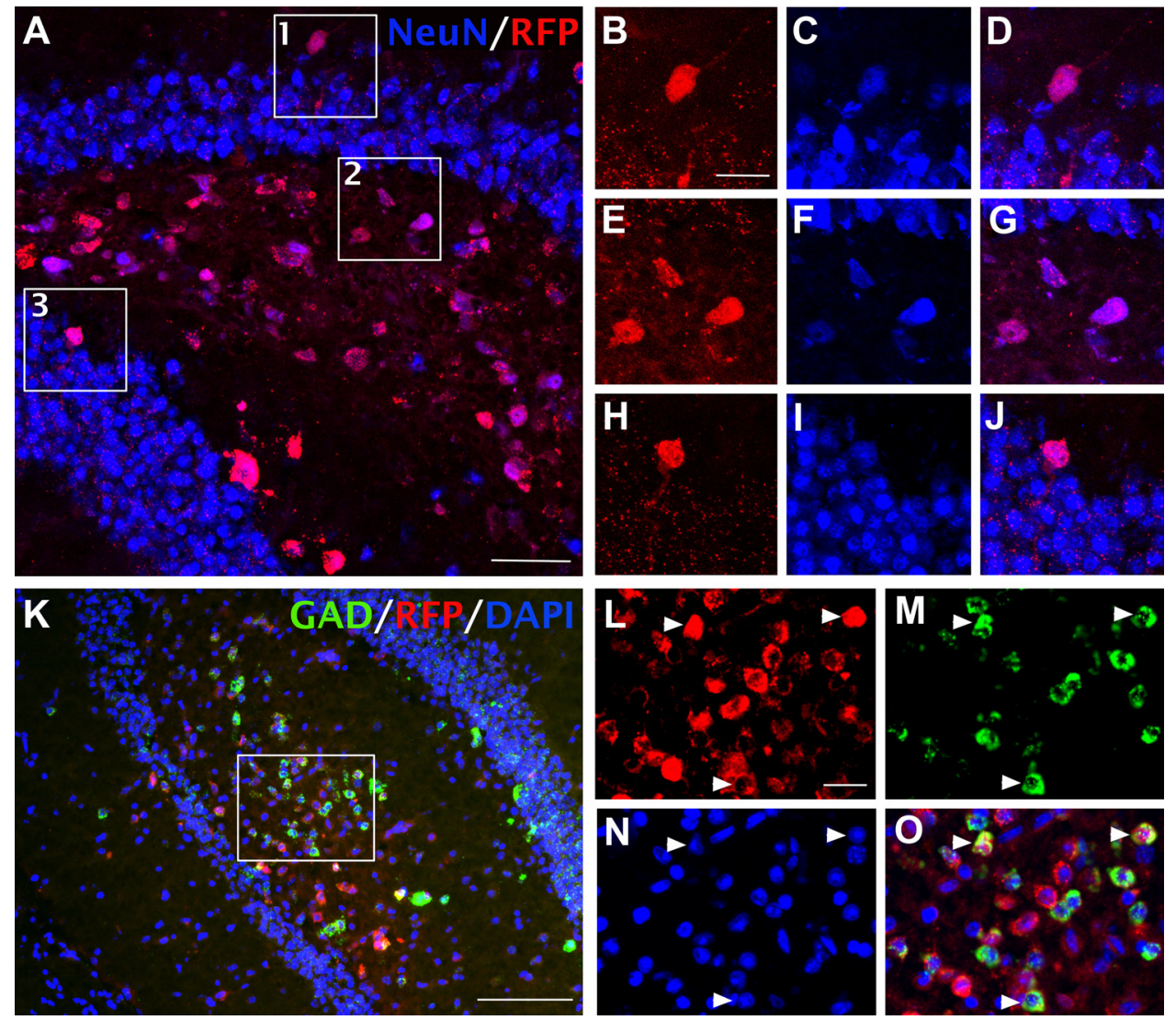

Figure 3. FISH analyses show that transplanted ESNPs in the dentate gyrus differentiate into GABAergic interneurons. $A-J$, Approximately $90 \%$ of the transplanted cells differentiated into neurons, ascertained by immunofluorescent staining for NeuN (87.4 $\pm 2.6 \% \mathrm{NeuN}^{+}$cells; $\left.n=6\right) . \boldsymbol{B}-\boldsymbol{J}$, Magnified views of boxed regions in $\boldsymbol{A}$ show NeuN-expressing transplanted cells. $\boldsymbol{K}-\boldsymbol{O}$, GAD1/2 mRNA expression was detected in nearly half of the transplanted cells $(48.9 \pm 3.0 \% ; n=6)$, as assessed by FISH. Arrowheads indicate RFP ${ }^{+}$cells expressing GAD1/2 mRNA. Scale bars: $A$, $50 \mu \mathrm{m} ; \boldsymbol{B}-\boldsymbol{J}, \mathbf{L}-\mathbf{O}, 20 \mu \mathrm{m} ; \boldsymbol{K}, 200 \mu \mathrm{m}$.

majority was located in the hilus and expressed the mature neuronal marker NeuN $(87.4 \pm 2.6 \% ; n=6)$ (Fig. $3 A-J)$. Only one mouse developed an apparent teratocarcinoma, in agreement with a previous study showing reduced tumorigenesis when progenitor cells acquire more differentiated phenotypes before transplantation (Seminatore et al., 2010).
Previous studies in rats and mice showed that status epilepticus induced by pilocarpine leads to a rapid and substantial loss of hilar GABAergic interneurons (Obenaus et al., 1993). To determine whether transplanting ESNPs restored hilar GABAergic interneuron populations, we used FISH for GAD1/2 mRNA and quantified hilar GABAergic interneurons in mice with or without 

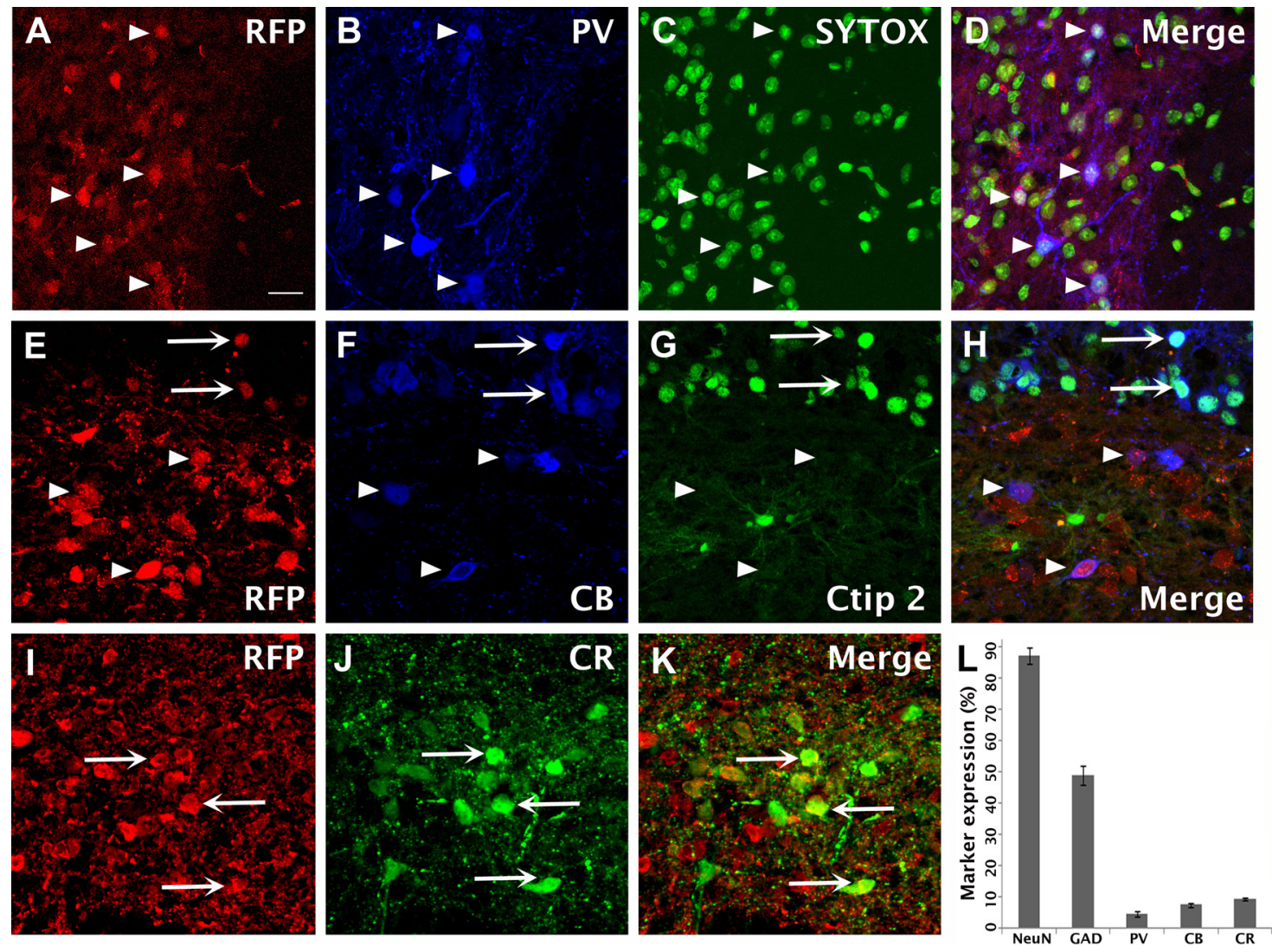

Figure 4. ESNPs differentiate into neurochemically distinct interneuron types after transplantation into the hilus of the dentate gyrus. $A-D$, Confocal images of RFP ${ }^{+}$ESNP-derived neurons in the dentate gyrus. Approximately $5 \%$ of transplanted cells express the calcium-binding protein parvalbumin ( $4.6 \pm 0.7 \% ; n=4$; arrowheads). $\boldsymbol{E}$ - $\boldsymbol{H}$, Approximately $8 \%$ express calbindin indicated by arrowheads $(7.5 \pm 0.7 \% ; n=5)$. Rare cells coexpress calbindin and ctip2 (arrows), suggesting that some ESNPs differentiate into excitatory, glutamatergic neurons. $\boldsymbol{I}-\boldsymbol{K}$, Nearly $10 \%(9.3 \pm$ $0.4 \%, n=4$ ) of the cells in hilar transplants expressed calretinin (arrows). $L$, Quantification of the neurochemical phenotypes ascertained for ESNP-derived neurons. Scale bars: $A-K, 20 \mu \mathrm{m}$.

SE. Pilot studies showed that in both TLE and non-TLE mice, we obtained much more reliable estimates of GABAergic interneurons by FISH than by immunostaining for GABA or glutamic acid decarboxylase. In mice that did not reach SE and, hence, did not develop TLE, the percentage of hilar neurons expressing GAD $1 / 2$ mRNA was $\sim 14 \%(13.7 \pm 2.8 \% ; n=3)$. In contrast, in mice that developed SE, only about half of the GABAergic interneurons in the hilus survived $(7.2 \pm 1.1 \% ; n=5)$. As expected, the TLE mice that received transplants of ESNPs showed a substantial recovery of GAD1/2 mRNA-expressing cells in the hilus (Fig. $3 K$ ). Quantitatively, nearly half of the transplanted $\mathrm{RFP}^{+}$neurons expressed GAD1/2 mRNA (48.9 $\pm 3.0 \%$; $n=6$ ) (Fig. $4 L$ ).

The immunohistochemical staining experiments suggested that $\sim 5 \%(4.6 \pm 0.7 \% ; n=4)$ of the $\mathrm{RFP}^{+}$transplanted neurons expressed PV, a calcium-binding protein indicative of a basket cell or chandelier cell (Kawaguchi et al., 1987; Katsumaru et al., 1988; Freund and Buzsáki, 1996) (Fig. 4A-D,L). The endogenous hippocampal PV-expressing interneurons are classified as fast spiking (Kawaguchi et al., 1987) and show marked neuroplastic changes in mice with TLE (Zhang and Buckmaster, 2009).

$\mathrm{CB}$ is a calcium-binding protein expressed both by GABAergic inhibitory interneurons and dentate granule cells and their axons (Szabadics et al., 2010). CB-expressing interneurons also exhibit neuroplastic alterations in TLE (Wittner et al., 2002). To determine the percentage of transplanted cells that were $\mathrm{CB}^{+}$subsets of GABAergic interneurons, we combined RFP staining with antibody staining for $\mathrm{CB}$ and ctip2. The ctip2 is a transcription factor expressed by excitatory projection neurons, including dentate granule cells (Leid et al., 2004; Arlotta et al., 2005; Molnár and Cheung, 2006; Chen et al., 2008). We identified the excitatory neurons in our transplants by triple labeling $\left(\mathrm{CB}^{+} / \mathrm{ctip}^{+} /\right.$ $\mathrm{RFP}^{+}$), allowing us to distinguish them from the GABAergic subset that was $\mathrm{CB}^{+} /$ctip $^{-} / \mathrm{RFP}^{+}$(Fig. $4 E-H$ ). $\mathrm{CB}$ was expressed in the $\mathrm{CA} 1-3$ regions, within subsets of hilar interneurons and nearly all dentate granule neurons. In the dentate granule cells and CA pyramidal cells, ctip 2 expression overlapped extensively with $\mathrm{CB}$ expression, but double labeling was rare in the hilar transplants. We inferred that the $\mathrm{RFP}^{+}$neurons expressing $\mathrm{CB}$ but not ctip2 were ESNP-derived neurons that had adopted a GABAergic phenotype. Accordingly, $\sim 8 \%$ of the RFP ${ }^{+}$ cells expressed CB $(7.5 \pm 0.7 \% ; n=5)$, and most were located in the hilus (Fig. $4 E-H, L$ ). Among these CB-expressing cells, $<1 \%$ coexpressed ctip2 (Fig. $4 E-H$ ), and, rarely, $\mathrm{RFP}^{+}$cells expressed ctip2 alone. These results suggest that a subset of transplanted cells became CB-expressing GABAergic interneurons and a very minor population of transplanted ESNPs differentiated into subtypes of excitatory neurons.

Next, we identified the populations of ESNP-derived neurons that were $\mathrm{CR}^{+}$. This subtype of GABAergic interneuron in the hippocampus preferentially synapses with other interneurons and strongly influences hippocampal excitability (Freund and Gulyás, 1997). CR interneurons also undergo neurodegeneration and reorganization in TLE (Tóth et al., 2010) and are, therefore, strong candidates for stem cell therapies to treat TLE. We deter- 

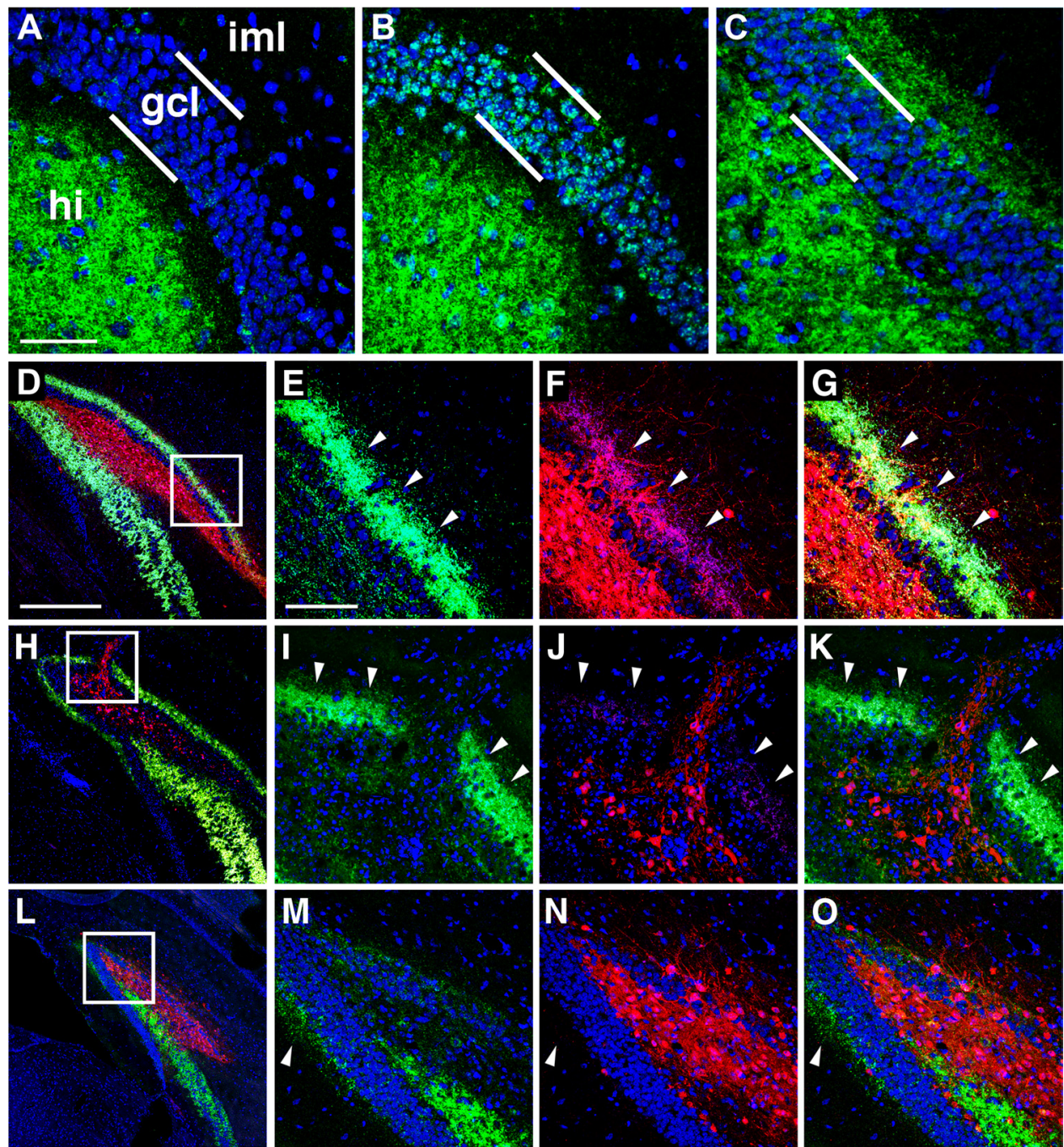

Figure 5. Transplanted cells displace mossy fibers in the hilus but fail to suppress MFS in the inner molecular layer. Dual immunohistochemical staining for transplanted ESNP-derived neurons in RFP (red) and mossy fibers expressing ZnT-3 (green) was used to evaluate MFS in the hilus and iml of the dentate gyrus in TLE mice. $A$, MFS is not observed in the granule cell layer or iml in normal mice without prior seizure experience, $\boldsymbol{B}$, TLE mice show moderate MFS by 6 weeks after SE after control stereotaxic injections of cell-culture medium devoid of ESNPs. $\boldsymbol{C}$, More than 3 months after SE, much more extensive MFS in the iml is typical (five of eight TLE cases showed extensive MFS in iml). In the hilus, however, mossy fibers rarely overlapped with ESNP-derived neuronal arbors, and the mossy fiber projections were often displaced in the vicinity of the graft cores $(n=8) . \boldsymbol{D}, \boldsymbol{H}$, Typically, RFP ${ }^{+}$axons from ESNP transplants invaded the iml and overlapped extensively with mossy fibers ( $n=5$ of 8 ). $\boldsymbol{E}-\boldsymbol{G}, \boldsymbol{I}-\boldsymbol{K}, \boldsymbol{L}, \boldsymbol{M}-\mathbf{0}$, Only three of eight mice with transplants exhibited reduced MFS ( $\boldsymbol{L}$ ), despite extensive innervation of the iml by the transplanted neurons in all cases $(\boldsymbol{E}-\boldsymbol{G}$,

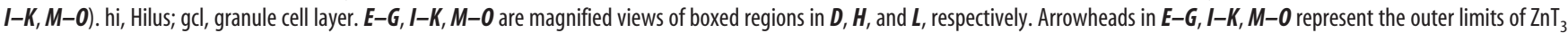
staining. Scale bars: $A-C, 50 \mu \mathrm{m} ; \boldsymbol{D}, \boldsymbol{H}, \mathbf{L}, 200 \mu \mathrm{m} ; \boldsymbol{E}-\mathbf{G}, \mathbf{I}-\boldsymbol{K}, \boldsymbol{M}-\mathbf{0}, 100 \mu \mathrm{m}$.

mined that nearly $10 \%$ of the ESNP-derived neurons expressed CR $(9.3 \pm 0.4 \% ; n=4)$ (Fig. $4 I-L)$.

Surprisingly, we did not detect SOM expression in transplanted neurons. We and others have shown that the SOMexpressing subtype of GABAergic interneuron in the hilus and CA1 undergoes rapid neurodegeneration after SE in the pilocarpine model in mice (Choi et al., 2007; Zhang et al., 2009), suggesting that these neurons may be more vulnerable to seizures than other hippocampal cell types.

Together, the quantitative results described above, based on mRNA expression and immunohistochemistry, suggest that many of the transplanted neurons within the dentate gyrus differentiated into subtypes of GABAergic interneurons that are injured or lost in TLE.

\section{Analysis of mossy fiber sprouting in TLE mice}

Next, we investigated whether ESNP-derived neuronal grafts alter or reduce mossy fiber sprouting (MFS). Considerable evi- dence suggests that MFS is a correlate of neuroplasticity and circuit reorganization in TLE, but whether this phenomenon is sufficient to cause recurrent seizures in TLE is still under debate. Two and four months after SE, MFS was compared in control mice subjected to SE followed by stereotaxic injections of medium without ESNPs versus experimental TLE mice with ESNP progenitor transplants. We visualized the extent of overlap between axonal arbors derived from the transplanted neurons in the red channel and the endogenous mossy fibers in the green channel using a doubleimmunofluorescent staining method and confocal microscopy. Representative findings are shown in Figure 5.

In naive mice not subjected to pilocarpine treatments, no MFS was observed in the molecular layer of the dentate gyrus (Fig. 5A). However, TLE mice that received control hippocampal injections of medium developed mossy fiber sprouting in the granule cell layer by 6 weeks after SE (Fig. 5B) and, after longer survivals, showed more extensive MFS in the inner molecular layer of the dentate gyrus (Fig. 5C). In addition, the normal mossy fiber path- 
way to CA3 was strongly labeled (not shown). In TLE mice that had large grafts of ESNP-derived neurons in the hilus, it was typical to find an extensive and continuous band of MFS throughout the inner molecular layer (iml) of the dentate gyrus (five of eight TLE mice; Fig. 5D-G). Interestingly, ESNP transplant-derived axons invaded the iml and formed overlapping projections with the band of MFS (Fig. $5 D-G, H-K$ ). In the hilus of TLE mice with transplants, the mossy fibers axons were typically displaced from the core of the grafts (Fig. 5D, $H, L$ ). In three of eight mice, we observed very little MFS (Fig. $5 L-O$ ), despite extensive innervation of the iml by the transplanted neurons in all cases. Interestingly, granule cell lesions seem to be one mechanism for disrupting MFS. In several animals, the injection track containing transplanted neurons penetrated through the superior blade of the granule cell layer. Only within this localized region of damage was mossy fiber sprouting abolished (Fig. $5 H-K$ ). Together, these results suggest that our ESNP-derived grafts formed extensive axonal projections within the host brain, particularly in the inner molecular layer and the hilus. However, in most instances, the transplanted neurons did not seem to have a marked effect on mossy fiber sprouting in the molecular layer of the dentate gyrus.

\section{Electrophysiological characteristics of transplanted cells}

We next asked whether the transplanted cells exhibited electrophysiological properties characteristic of GABAergic interneurons or glutamatergic neurons. Single whole-cell patch-clamp recordings were performed in hippocampal slices from mice 2-3 months after ESNPs were transplanted. We targeted transplanted neurons in the hippocampal slices using RFP and differential interference contrast (DIC) views (Fig. 6A-C). We recovered the morphologies of 15 of these neurons. Of these, 14 were located in the dentate gyrus, and the remaining one was in the stratum oriens of CA1 (Fig. 6D).

Of the 30 successfully recorded cells, the average resting membrane potential was $-51 \pm 1.5 \mathrm{mV}$ (recordings from two neurons deteriorated before characterization of their respective firing patterns, and so they were discarded from the electrophysiological measurements). AP trains were evoked with 500 ms current injections. During negative current injections, 13 of the 30 cells $(43 \%)$ showed hyperpolarization-activated currents ( $I_{\mathrm{h}}$ currents), whereas 11 cells displayed rebound APs after termination of hyperpolarizing currents. Two of the cells had rebound APs in a bursting mode. Overall, the transplanted cells had short AP half-widths, $0.98 \pm 0.07$ $\mathrm{ms}$ (range, $0.49-2.4 \mathrm{~ms}$; median, $0.9 \mathrm{~ms}$ ), and high input resistances, $685 \pm 56 \mathrm{M} \Omega$ (range, 203-1645 M $\Omega$; median, $623 \mathrm{M} \Omega$ ). These electrophysiological parameters are somewhat comparable to GIN neurons, a subtype of GABAergic interneuron (Table 3).

Based on the presence or absence of the $I_{\mathrm{h}}$ current and the firing patterns described above, we grouped the neurons into five types (Table 3, Fig. 7). Type I and II cells showed $I_{\mathrm{h}}$ currents with one exception within the type II class (Fig. 7, top, A). Type I cells
( $n=10)$ exhibited strong accommodation (decreasing AP amplitudes); half of these cells stopped firing before the termination of stimulation. Type II cells $(n=4)$ showed small AP amplitudes and negative AP drops (Fig. 7, top, $B$ ). $I_{\mathrm{h}}$ current was present in three of the four cells in this group. One of four cells had strong accommodation. Type III cells $(n=11)$ resembled type I cells, except for the absence of $I_{\mathrm{h}}$ current (Fig. 7, top, $C$ ). All type III cells showed strong accommodation. Type IV cells $(n=4)$ displayed fast-spiking firing trains and relatively constant AP amplitude; no cells showed strong accommodation (Fig. 7, top, D). The type $\mathrm{V}$ category included only one cell, which was recorded from the granule cell layer. This cell had a long AP half-width and low input resistance compared with other types (Fig. 7, top, E), consistent with the properties of dentate granule cells. With the exception of the type $\mathrm{V}$ cell, recorded transplanted cells exhibited electrophysiological characteristics consistent with GABAergic subtypes (compare with Fig. $7 F$ ).

\section{Functional incorporation of ESNPs into the host brain}

To examine whether the transplanted cells form synaptic connections with the host brains, we compared spontaneous EPSCs from endogenous hilar interneurons (recorded from GIN mice) with transplanted neurons, by performing voltage-clamp recordings at a $-70 \mathrm{mV}$ holding potential (Fig. 8). The spontaneous EPSCs were recorded in 6 of the 30 neurons described above; their average frequency of EPSCs was $3.4 \pm 0.6 / \mathrm{s}$ compared with $23 / \mathrm{s}$ in a GIN interneuron. The transplanted neurons had an average EPSC amplitude of $-13.5 \pm 1.3 \mathrm{pA}$, which was much smaller than the average amplitude of $-35.6 \mathrm{pA}$ recorded from the GIN interneuron. Overall, the median amplitude of the trans- 
Table 3. Categorization of transplanted ESNP-derived neurons based on electrophysiological properties

\begin{tabular}{|c|c|c|c|c|c|c|c|}
\hline Parameter & Type I (10) & Type II (4) & Type III (11) & Type IV (4) & Type V (1) & GIN (5) & $p<0.05$ \\
\hline Membrane potential (mV) & $-48.50 \pm 2.4$ & $-52.3 \pm 3.1$ & $-49.4 \pm 2.5$ & $-58.0 \pm 2.7$ & -68 & $-44.7 \pm 2.6$ & \\
\hline Delay to spike (ms) & $19.7 \pm 4.2$ & $15.2 \pm 6.1$ & $18.0 \pm 3.9$ & $12.7 \pm 4.3$ & 44.2 & $16.6 \pm 4.2$ & \\
\hline Spike threshold (mV) & $-38.7 \pm 1.7$ & $-39.0 \pm 4.0$ & $-40.8 \pm 2.3$ & $-40.8 \pm 4.3$ & -22.5 & $-41.8 \pm 1.2$ & \\
\hline AP amplitude (mV) & $67.1 \pm 2.9$ & $29 \pm 2.6$ & $63 \pm 3.9$ & $62 \pm 6.2$ & 31.3 & $59.5 \pm 6.0$ & $\begin{array}{l}\text { I-II, } \\
\text { II-III, } \\
\text { II-IV, II-GIN }\end{array}$ \\
\hline AP half-width (ms) & $0.82 \pm 0.06$ & $1.13 \pm 0.43$ & $1.04 \pm 0.1$ & $0.78 \pm 0.09$ & 2.1 & $0.96 \pm 0.1$ & \\
\hline AP drop (mV) & $6.0 \pm 1.4$ & $-2.3 \pm 0.4$ & $7.1 \pm 1.6$ & $3.2 \pm 1.4$ & 4.5 & $0.8 \pm 1.2$ & $\begin{array}{l}\mid-\|, \\
\|-\| \mid\end{array}$ \\
\hline Maximum frequency $(\mathrm{Hz})$ & $46.5 \pm 3.2$ & $50.7 \pm 12.3$ & $50.4 \pm 8.1$ & $55.2 \pm 8.7$ & 18.4 & $69.9 \pm 17.6$ & \\
\hline Maximum number of APs & $19.4 \pm 2.4$ & $24.5 \pm 6.0$ & $9.5 \pm 1.0$ & $25.8 \pm 5.0$ & 8 & $20.3 \pm 6.7$ & $\begin{array}{l}\text { I-III, } \\
\text { II-III, } \\
\text { III-IV }\end{array}$ \\
\hline Adaptation & $2.0 \pm 0.2$ & $2.2-0.3$ & $2.3 \pm 0.3$ & $2.1 \pm 0.2$ & 2.3 & $1.6 \pm 0.3$ & \\
\hline AHP1 amplitude (mV) & $-18.1 \pm 2.6$ & $-7.9 \pm 1.6$ & $-15.0 \pm 2.0$ & $-16.6 \pm 1.9$ & -9.3 & $-11.6 \pm 1.8$ & \\
\hline AHP2 amplitude (mV) & $-4.1 \pm 0.9$ & $-6.1 \pm 2.3$ & $-0.7 \pm 0.7$ & $-3.3 \pm 1.2$ & 0 & $-1.6 \pm 1.6$ & $\|-\| \|$ \\
\hline Voltage sag ratio & $1.47 \pm 0.08$ & $1.63 \pm 0.26$ & $1.01 \pm 0.01$ & $1.03 \pm 0.03$ & 1 & $1.17 \pm 0.07$ & $\begin{array}{l}\text { I-IV, } \\
\text { I-III, } \\
\text { II-III, } \\
\text { II-IV, II-GIN }\end{array}$ \\
\hline Input resistance (M $\Omega$ ) & $717 \pm 98$ & $450 \pm 51$ & $784 \pm 107$ & $641 \pm 92$ & 377 & $529 \pm 83$ & \\
\hline
\end{tabular}

planted neurons was $-9.8 \pm 1.2 \mathrm{pA}$ compared with $-29.7 \mathrm{pA}$ from the GIN interneuron (Fig. 8).

\section{Morphological diversity of transplanted cells}

Biocytin was perfused into the cells during electrophysiological recordings to allow morphological analyses of the transplanted neurons. Fifteen of the 30 neurons analyzed electrophysiologically were also compared morphologically. Their approximate locations in the transplants were plotted onto a standard coronal section of the mouse brain for comparisons (Fig. 6D). Of the 15 biocytin-filled cells, 8 were located in the hilus including 2 on the border of the granule cell layer and the hilus (cells 27 and 32); six others were located in the outer molecular layer of the dentate gyrus, and one was in the stratum oriens of CA1. Two of the neurons recorded from the molecular layer (cells 23 and 24) had a bipolar dendritic morphology. Two of the neurons located deep in the hilus (cells 5 and 7) had three to four long aspinous dendrites that emerged from the soma and traveled in multiple directions; resembling the aspiny stellate cells described in a previous study [Amaral (1978), his Fig. 27]. One cell (cell 8; Fig. $9 E, F$ ) located adjacent to the upper blade of the dentate gyrus exhibited an oval-shaped soma that had seven primary dendrites running in opposite directions parallel to the upper blade of the dentate gyrus. The putative axon traveled parallel with the dentate gyrus before turning toward the hilus. The dendritic morphology of this cell resembled the HIPP cells (hilar neuron with its axon distributed in the perforant path termination zone) described previously (Freund and Buzsáki, 1996). The firing of this cell belongs to type I with $I_{\mathrm{h}}$ current (Figs. 7A, 9F). Cell 15 (Fig. $9 G, I)$, also located adjacent to the upper blade of the dentate gyrus, had two primary dendrites, and each branched off into secondary dendrites. One dendrite with thin, sparse dendritic spines traveled $\sim 400 \mu \mathrm{m}$, running parallel to the upper blade of the dentate gyrus. The firing of this cell belongs to type III with bursting rebound APs but no apparent $I_{\mathrm{h}}$ current (Figs. 7C, 9I). Cell 32 (Fig. 9A-D), located at the border of the granule cell layer and the hilus, had a triangular-shaped soma and exhibited fastspiking firing properties. This neuron had several primary dendrites that traveled obliquely to the granule cell layer and readily branched to generate secondary dendrites, several of which traversed the granule cell layer into the molecular layer of the dentate gyrus. The firing properties of this cell are characteristic of type IV, with high firing frequencies and low adaptation, resembling a basket cell (Kawaguchi et al., 1987; Freund and Buzsáki, 1996; Lübke et al., 1998).

\section{Discussion}

Our immunohistochemical, molecular, and electrophysiological data suggest that murine ESNPs transplanted into the hilus of the dentate gyrus in mice with TLE undergo differentiation into GABAergic interneurons and other neuronal types. Despite disease-associated mossy fiber sprouting and degeneration of the endogenous GABAergic interneurons, many of the transplanted GABAergic interneurons survive over 3 months after transplantation and form extensive axonal projections within the host dentate gyrus. Importantly, the transplanted neurons develop functionally into subtypes of inhibitory GABAergic interneurons, exhibiting electrophysiological properties characteristic of normal hilar interneurons. These findings suggest that ES cellbased therapies have considerable potential to replace hippocampal GABAergic interneurons that undergo excitotoxic cell death or become dysfunctional in neurological diseases.

\section{Rationale for GABAergic interneuron replacement in temporal lobe epilepsy}

Although studies have established that ES cells are an excellent cell source for producing neurons and glia, and clinical trials have commenced to determine efficacy for treating spinal cord injury and neurodegeneration, few studies have been conducted to examine whether ES-derived GABAergic interneurons exhibit long-term survival and differentiation in models of severe, drugresistant forms of epilepsy. Therefore, the present work addresses an important gap in our current knowledge. Typically, stem cellbased therapies are considered for severe neurodegenerative disorders, such as Parkinson's disease, characterized by primary degeneration of one neuronal cell type. In temporal lobe epilepsy, approximately one-third of adult patients show focal metabolic abnormalities detected by positron emission tomography (PET), 


\section{Firing properties of transplanted cells}

$n=30$
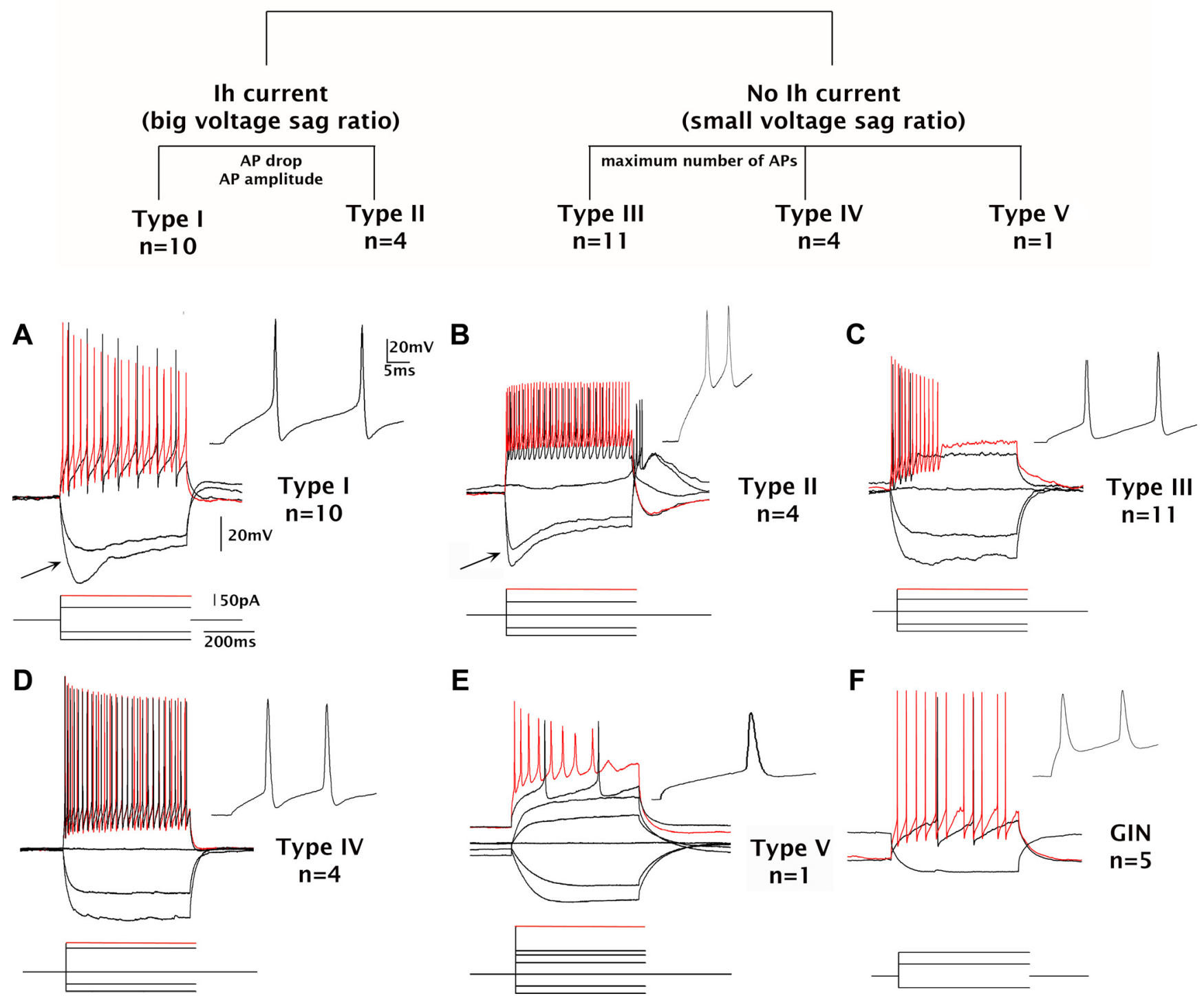

$\mathbf{E}$

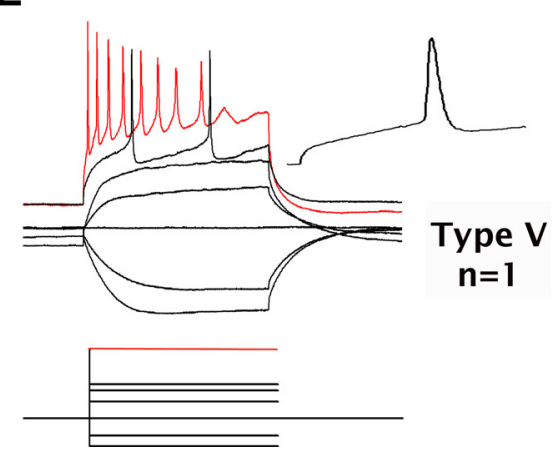

$\mathbf{F}$
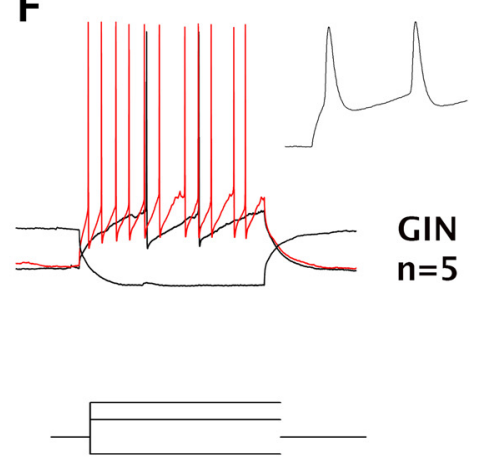

Figure 7. The majority of neurons displayed electrophysiological characteristics of endogenous hippocampal GABAergic interneurons. Top, Neurons are classified based on the presence (types I and II) or absence of $I_{\mathrm{h}}$ current (types III, IV, and V). Types I and II are distinguished by AP drop and AP amplitude. Types III and IV are distinguished by the maximum number of APs in response to depolarizing currents. The type $V$ category contains one cell with a large AP half-width recorded from the granule cell layer. $A$, Type I cells exhibit $/ \mathrm{h}$ currents (arrow) and prominent AP drops. $B$, Type II cells exhibit $I_{h}$ currents (arrow) and significantly smaller APs compared with other types. This type also exhibits trains of fast APs. C, Type III neurons resemble type I cells, but without $I_{h}$ currents. $D$, Type IV neurons exhibit small AP drops and fast-spiking APs without $l_{h}$ currents. $E$, Type $V$ neurons are found in the granule cell layer of the dentate gyrus and resemble granule neurons based on AP half-width and small fast afterhyperpolarizations. $F$, A GIN neuron recorded from the hilus exhibits firing patterns similar to those from ESNP-derived transplants. Calibration is as indicated.

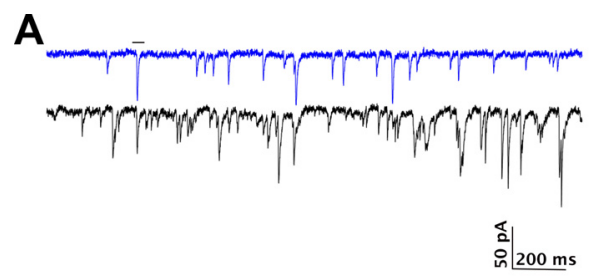

B

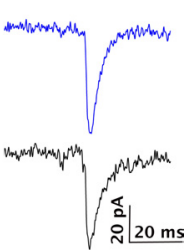

Figure 8. Electrophysiology of transplanted neurons into the host brain circuitry. $\boldsymbol{A}$, The top trace shows a 2 s sample from a voltage-clamp recording at $-70 \mathrm{mV}$ demonstrating spontaneous EPSPs in a transplanted neuron. In the bottom traces, for comparison, spontaneous EPSPs were recorded from an endogenous somatostatin-expressing interneuron in a GIN mouse. $\boldsymbol{B}$, Enlarged views of the individual EPSCs from neurons in $\boldsymbol{A}$ are presented in the highlighted region. Calibration is as indicated. and many develop multiple-drug-resistant seizure foci originating in the temporal lobes. Sclerosis, indicative of neuronal injury and cell loss, and loss of GABAergic interneurons has been shown in many patients who develop severe recurrent seizures after a traumatic brain injury or prolonged febrile seizures. These patients would be considered candidates for more invasive approaches, including deep brain stimulation, corpus callosotomy, gene therapy, or neuronal replacement therapy. The latter two approaches have the advantage that they could provide a cure for the underlying disease, by restoring a balance between excitation and inhibition in limbic circuits. Before these more invasive procedures can be used in the clinic, extensive safety and efficacy studies are needed to determine feasibility for each approach. As a first step, we performed experiments in the mouse pilocarpine model. Although systemic pilocarpine-induced TLE in mice is 

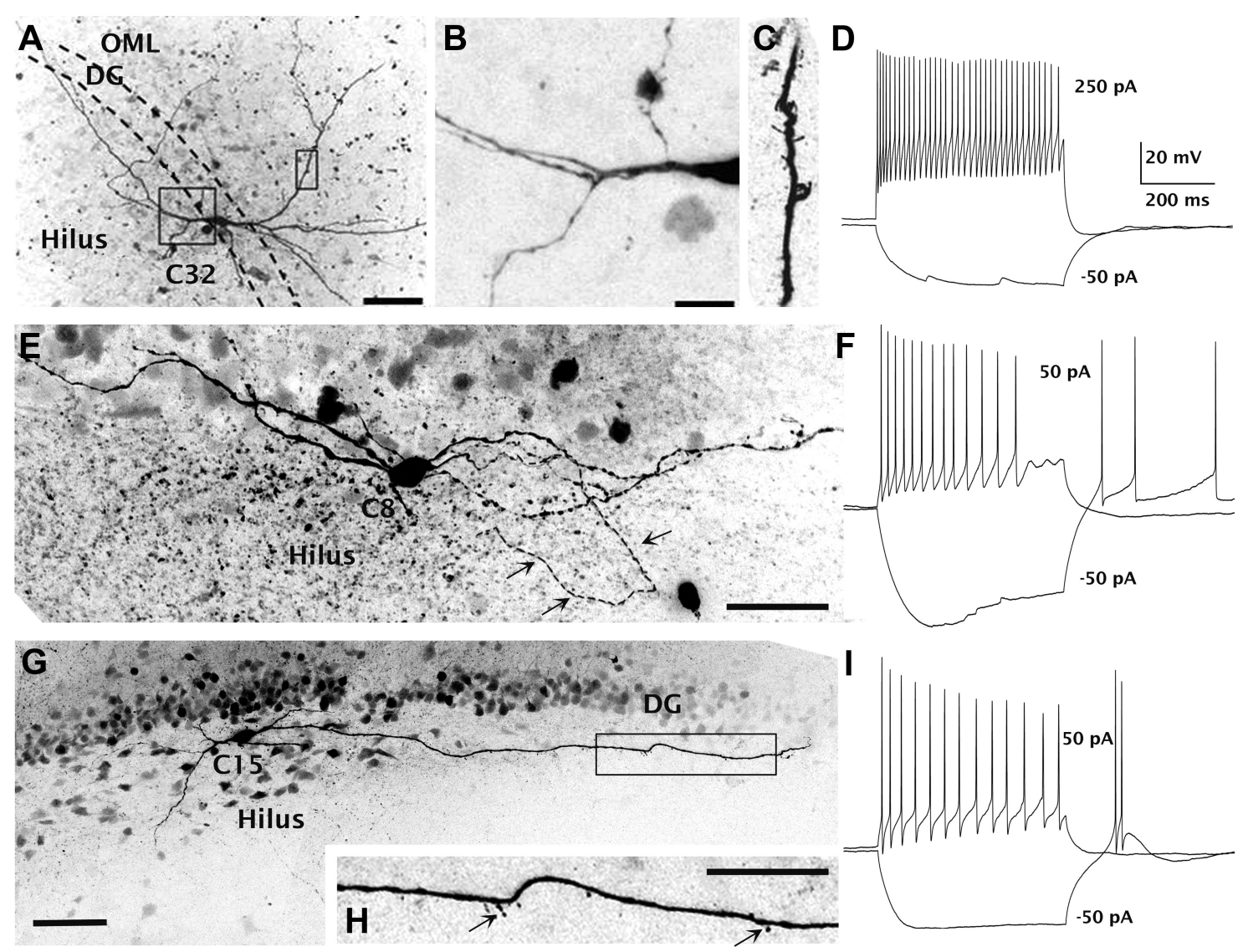

Figure 9. Transplanted cells exhibit morphologies and firing patterns resembling endogenous GABAergic interneurons. $A-D$, An example of one of the transplanted neurons (cell 32 ) located in the granule cell layer that exhibited typical basket cell morphology $(\boldsymbol{A})$ and a fast-spiking firing pattern (D). Boxed regions in $\boldsymbol{A}$ are shown in $\boldsymbol{B}$ and $\boldsymbol{C}$. Primary dendrites emerged from the soma and bifurcated in the hilus before traveling obliquely to the granule cell layer $(\boldsymbol{B})$. This cell has sparse dendritic spines $(\boldsymbol{C})$. $\boldsymbol{E}, \boldsymbol{F}$, Another transplanted neuron (cell $8 ; \boldsymbol{E})$ located near the upper blade of the dentate gyrus has a dendritic morphology resembling HIPP cells. Electrophysiological classification of this cell was type I with $I_{\mathrm{h}}$ current $(\boldsymbol{F})$. $G, \boldsymbol{I}$, A neuron (cell 15 ) located near the upper blade of the granule cell layer forms dendrites running parallel with the dentate gyrus. $\boldsymbol{H}$, The primary dendrites are aspiny, but dendritic spines are present $\sim 200 \mu \mathrm{m}$ from the soma (arrows). This cell is classified electrophysiologically as type IV, with bursting rebound action potentials. Scale bars: $A, E, H, 50 \mu \mathrm{m} ; \boldsymbol{B}, \mathbf{C}, 25 \mu \mathrm{m} ; \mathbf{G}, 100 \mu \mathrm{m}$.

not a perfect replica of human TLE, many consider it to be a stringent model for testing cell-based treatments for drugresistant forms of TLE. In C57BL/6 mice, $1 \mathrm{~h}$ of SE results in rapid degeneration of GABAergic interneurons in the hippocampus and entorhinal cortex. Many of the mice subsequently develop spontaneous recurrent seizures and sclerosis in the hippocampus and associated limbic structures, as well as mossy fiber sprouting. Additional molecular and metabolic abnormalities in these mice replicate many of the features of severe TLE in human patients.

In agreement with previous studies, the proportion of surviving hilar GABAergic interneurons is very low after 1 -h-long pilocarpine-induced SE $(7.2 \pm 1.1 \%$ GAD2-expressing cells per coronal section; $n=5)$. We show that TLE mice treated with ESNP transplants have nearly twice as many hilar GABAergic interneurons as TLE mice with media injections (13.7 $\pm 2.8 \%$ GAD2-expressing cells per coronal section; $n=$ 3 ), suggesting that transplantation was able to double the number of GABAergic cells in the dentate hilus. This density of surviving GABAergic neurons is twofold higher than what has been previously reported after transplantation in a mouse epilepsy model with human fetal-derived stem cells (Chu et al., 2004), but lower than the proportion reported after fetal MGE transplants of GABAergic progenitors (Baraban et al., 2009; Zipancic et al., 2010). These results suggest that ESNP-derived
GABAergic interneurons can replace populations of neurons damaged in chronic epilepsy.

Several additional issues need further evaluation before stem cell-based approaches can be considered promising for treating severe TLE. It must be demonstrated that cell grafts do not produce teratomas and can reduce seizures beyond what is now possible with anticonvulsant medications. Some TLE patients downregulate postsynaptic $\mathrm{GABA}_{\mathrm{A}}$ receptors, which may explain why medications that target $\mathrm{GABA}_{\mathrm{A}}$ receptors are often ineffective in these patients (Brooks-Kayal et al., 1998). Enhanced synaptic inhibition and good seizure control may require normalization of cellular expression of $\mathrm{GABA}_{\mathrm{A}}$ receptors, and this can now be investigated using the experimental paradigm that we have described. In addition, it will be important to test whether ES cell-derived GABAergic neurons alleviate memory disorders and anxiety, often associated with severe TLE. Whereas our electrophysiological data suggest that the transplanted neurons incorporate into adult hippocampal circuits, it is not yet clear whether they exert sufficient activity-dependent synaptic inhibition to suppress spontaneous seizures. Moreover, given the involvement of a larger circuit involving the entorhinal cortex, dentate gyrus, and Ammon's horn in seizure propagation, it seems likely that transplantation into multiple sites will be required before therapeutic benefits can be realized. We believe that 
our findings now establish an experimental paradigm for examining these important issues.

\section{Mossy fiber sprouting in mice with ESNP transplants}

MFS is a form of granule cell neuroplasticity and a correlate of SRSs that is prevented by inhibitors of the mTOR (mammalian target of rapamycin) signaling pathway (Buckmaster et al., 2009; Buckmaster and Lew, 2011; Shibley and Smith, 2002), and we therefore investigated whether ESNP grafts made 2 weeks after SE could prevent or reduce MFS. Consistent with previous work, the mice subjected to $\sim 1 \mathrm{~h}$ of pilocarpine-induced SE followed by seizure reduction with diazepam developed robust MFS, as shown by labeling for $\mathrm{ZnT}_{3}$, enriched in synaptic vesicle membranes of mossy fiber axons (Wenzel et al., 1997). Interestingly, the axonal arbors derived from transplanted neurons and granule neurons showed extensive overlap in the molecular layer of the dentate gyrus, where MFS occurs. Although our results show that the ESNP grafts have only a modest effect on MFS, in future studies, it would be of considerable interest to evaluate whether the ESNP-cell derived axons enhance levels of synaptic inhibition onto granule neurons.

Inflammation and immune modulation in drug-resistant TLE Mounting evidence suggests that drug-resistant forms of refractory temporal lobe epilepsy are linked to increased blood-brain barrier permeability and activation of pro-inflammatory signaling cascades (Vezzani and Granata, 2005; Vezzani et al., 2008). It is also likely that there is an initial neuroimmune component in the rodent lithium-pilocarpine model, as systemic pilocarpine stimulates peripheral inflammation by decreasing the ratio of CD4/CD8 T-lymphocytes and causes a spike in serum IL- $1 \beta$ (Marchi et al., 2007). Correspondingly, IL-1 $\beta$ receptor antagonists (Marchi et al., 2009) or neuroactive steroids (Kokate et al., 1996) reduce epileptogenesis in the pilocarpine model, suggesting that anti-inflammatory drugs may be more effective than many conventional anticonvulsant medications for treating severe TLE. However, because of sclerosis and neurodegeneration in some patients, treatments targeting inflammation are unlikely to cure the underlying disease. Interestingly, bone marrowderived mesenchymal stem cell transplants in rodents reduce inflammation caused by traumatic brain injury (Galindo et al., 2011) or neurodegeneration (Xiong et al., 2010), suggesting that stem cell grafts may have anti-inflammatory effects in the brain. The ES cell lines in our studies were derived from the 129 strain of inbred mice, and because of marked interstrain differences in responses to pilocarpine, we use C57BL/6 male mice from Harlan. To avoid graft versus host disease, we immunosuppressed the mice by chronic cyclosporine treatment in their drinking water, beginning several days before ESNP grafting and continuing immunosuppression until the day the mice were killed. Thus, under the conditions of our study, the influence of inflammation on graft survival or differentiation is probably very low.

\section{Efficiency of GABAergic interneuron production in vitro}

We generated ESNPs for transplantation using nutrient-poor medium in a feeder-free monolayer culture system (Ying and Smith, 2003) and applied a hedgehog agonist in vitro to promote survival and differentiation of GABAergic progenitors (Barberi et al., 2003; Li et al., 2009; Sousa and Fishell, 2010; Xu et al., 2010). Immunohistochemical data indicate that a significant subset of the ESNP-derived neurons expressed calcium-binding proteins, typical of many of the neocortical GABAergic interneurons. In ad- dition, these cells expressed the basal forebrain markers $D l x 2$ and $G A D 2$, again indicative of GABAergic interneuron progenitors.

These results suggest that our starting population of cells is already enriched for GABAergic progenitors. However, effective neuronal replacement in human TLE may require additional strategies to enrich for GABAergic interneuron subtypes, as SOM-expressing interneurons are quite rare in our transplants. Several possible explanations may account for the low numbers of SOM interneurons in our hilar transplants. First, our in vitro protocol may not promote neurogenesis of SOM-expressing interneurons. One strategy would be to enrich for this type by using lineage-specific markers such as Lhx6 (Maroof et al., 2010). For translation into the clinic, it will also be necessary to identify cell-surface antigens expressed by human GABAergic interneurons so that higher yields of viable interneurons can be obtained from human ES cells or induced pluripotent stem cells (IPSCs) by fluorescence-activated cell sorting. Second, the low yields of ESNP-derived SOM-expressing interneurons in our transplants may be attributable to relative insensitivity of our staining method, compared with previous studies (Buckmaster and Jongen-Rêlo, 1999). A third possible explanation for the low levels of SOM-expressing GABAergic interneurons is that ESNPderived SOM-expressing interneurons die off after transplantation. The stem cell niche in the adult dentate gyrus reportedly promotes genesis of PV interneurons but not other GABAergic cell types (Liu et al., 2003), and we transplanted into anterior, dorsal hippocampus, a region that normally has relatively few SOM-expressing interneurons compared with other hippocampal areas (Zhang et al., 2009). Moreover, although seizures induce BDNF expression (Silva et al., 2009), the amount produced may not be sufficient for survival of SOM-expressing progenitors in epileptic tissue.

Approximately $10 \%$ of the interneurons surviving in our transplants expressed the calcium-binding protein CR. These GABAergic interneurons are normally found in higher numbers in the hilus of the dorsal hippocampus (Blasco-Ibáñez and Freund, 1997). In contrast to many other subtypes of GABAergic interneurons, the CR-expressing interneurons in the hilus selectively innervate other interneurons and are postulated to synchronize hippocampal inhibition (Gulyás et al., 1996; Freund and Gulyás, 1997). Postmortem studies of resected hippocampal tissue from human patients with TLE reveal fivefold to eightfold decreases in the density of CR-expressing interneurons (Tóth et al., 2010), suggesting that this cell type also undergoes neurodegeneration. Loss of CR-expressing neurons may desynchronize the firing of other interneurons and thereby reduce the level of inhibition onto dentate granule cells (Tóth et al., 2010). Therefore, our finding that we have replenished this cell population has significant implications for developing cell-replacement therapies to suppress seizures in TLE.

\section{Electrophysiological studies of synaptic integration of transplanted neurons}

Interneuron subtypes are characterized by their specific gene expression profiles (Nelson et al., 2006; Sugino et al., 2006) and diverse physiological and morphological characteristics (Miyoshi et al., 2007), making their classification exceptionally complex and controversial. As more interneuron subtypes are identified, it becomes difficult to use electrophysiology alone to distinguish these subtypes. In addition to dendritic and axonal morphology, statistical tools such as cluster analysis are used to parse unique interneuron subtypes (Halabisky et al., 2006; McGarry et al., 2010; Guerra et al., 2011). However, because of our limited sample size and the diversity 
of phenotypes we observed, we are not able to perform unsupervised cluster analysis to classify the transplanted neurons.

Nevertheless, we identified patterns of physiological properties of transplanted cells that support our immunohistochemical analyses. Two to three months after transplantation, the neurons exhibit mature firing properties and morphologies. Most have short AP durations and large and fast afterhyperpolarizations after each action potential, properties that are usually indicative of GABAergic interneurons in the hippocampus (Lacaille and Williams, 1990; Sik et al., 1995; Jonas et al., 2004).

Approximately $50 \%$ of the cells exhibit $I_{\mathrm{h}}$ current, and $\sim 30 \%$ show rebound action potentials, an indication of the presence of hyperpolarization-activated ion channels that are often found in pyramidal neurons and hippocampal GABAergic interneurons (Maccaferri and McBain, 1996; Robinson and Siegelbaum, 2003). $I_{\mathrm{h}}$ current is involved in pacemaking activities of the hippocampus (Robinson and Siegelbaum, 2003) and is implicated in regulating neuronal integration by enhancing temporal precision of coincidence detection in the hippocampus (Pavlov et al., 2011). In agreement with our findings, a previous study found that ES cell-derived neurons exhibit $I_{\mathrm{h}}$ currents after transplantation into adult rodents with pilocarpine-induced TLE (Ruschenschmidt et al., 2005).

Although stem cell transplantation has been considered as a mechanism for drug delivery in epilepsy, to achieve activitydependent control of seizures, it is necessary for the transplanted neurons to form functional synapses with neurons in the host brain. Transplanted neural progenitors derived from the MGE, an embryonic region of the forebrain that generates GABAergic interneurons, were shown to establish electrophysiological synaptic contacts (Baraban et al., 2009; Calcagnotto et al., 2010; Zipancic et al., 2010). To evaluate the extent of functional integration of ESNP-derived neurons in the mouse pilocarpine model, we conducted voltage-clamp recordings. Our results showing that transplanted neurons receive excitatory synaptic connections suggest that the ESNPs functionally integrated into the epileptic circuits of the host brains. Furthermore, our single-cell electrophysiological studies suggest that the ESNP-derived neurons express functional ion channels capable of generating interneuronlike firing properties. Comparisons between the electrophysiological properties exhibited by transplanted ESNP-derived neurons in mice with TLE versus endogenous somatostatin-expressing interneurons in the hilus of adult GIN mice without TLE showed that the transplanted neurons have relatively fewer and smaller EPSCs. These data suggest that at the time of the recordings, the transplanted cells may still be forming synaptic connections with the host brain.

\section{Summary and conclusions}

We have shown in adult mice with TLE that transplanted ESNPs differentiate into GABAergic interneurons and functionally integrate into the hilus of the dentate gyrus. The results support a model that these progenitors may be particularly well suited for neural repair in severe drug-resistant forms of temporal lobe epilepsy. Additional studies to determine the functional outcomes of ESNP-derived GABAergic interneurons on seizures, sclerosis, inflammation, and cognition would address important gaps in our understanding of the potential for cell-based therapies for treating intractable forms of human temporal lobe epilepsy.

\section{References}

Alvarez-Dolado M, Calcagnotto ME, Karkar KM, Southwell DG, Jones-Davis DM, Estrada RC, Rubenstein JL, Alvarez-Buylla A, Baraban SC (2006) Cortical inhibition modified by embryonic neural precursors grafted into the postnatal brain. J Neurosci 26:7380-7389.
Amaral DG (1978) A Golgi study of cell types in the hilar region of the hippocampus in the rat. J Comp Neurol 182:851-914.

Arlotta P, Molyneaux BJ, Chen J, Inoue J, Kominami R, Macklis JD (2005) Neuronal subtype-specific genes that control corticospinal motor neuron development in vivo. Neuron 45:207-221.

Aubry L, Bugi A, Lefort N, Rousseau F, Peschanski M, Perrier AL (2008) Striatal progenitors derived from human ES cells mature into DARPP32 neurons in vitro and in quinolinic acid-lesioned rats. Proc Natl Acad Sci U S A 105:16707-16712.

Baraban SC, Southwell DG, Estrada RC, Jones DL, Sebe JY, Alfaro-Cervello C, García-Verdugo JM, Rubenstein JL, Alvarez-Buylla A (2009) Reduction of seizures by transplantation of cortical GABAergic interneuron precursors into Kv1.1 mutant mice. Proc Natl Acad Sci U S A 106:15472-15477.

Barberi T, Klivenyi P, Calingasan NY, Lee H, Kawamata H, Loonam K, Perrier AL, Bruses J, Rubio ME, Topf N, Tabar V, Harrison NL, Beal MF, Moore MA, Studer L (2003) Neural subtype specification of fertilization and nuclear transfer embryonic stem cells and application in parkinsonian mice. Nat Biotechnol 21:1200-1207.

Bertrand N, Castro DS, Guillemot F (2002) Proneural genes and the specification of neural cell types. Nat Rev Neurosci 3:517-530.

Blasco-Ibáñez JM, Freund TF (1997) Distribution, ultrastructure, and connectivity of calretinin-immunoreactive mossy cells of the mouse dentate gyrus. Hippocampus 7:307-320.

Briata P, Di Blas E, Gulisano M, Mallamaci A, Iannone R, Boncinelli E, Corte G (1996) EMX1 homeoprotein is expressed in cell nuclei of the developing cerebral cortex and in the axons of the olfactory sensory neurons. Mech Dev 57:169-180.

Brooks-Kayal AR, Shumate MD, Jin H, Rikhter TY, Coulter DA (1998) Selective changes in single cell GABA(A) receptor subunit expression and function in temporal lobe epilepsy. Nat Med 4:1166-1172.

Buckmaster PS, Jongen-Rêlo AL (1999) Highly specific neuron loss preserves lateral inhibitory circuits in the dentate gyrus of kainate-induced epileptic rats. J Neurosci 19:9519-9529.

Buckmaster PS, Lew FH (2011) Rapamycin suppresses mossy fiber sprouting but not seizure frequency in a mouse model of temporal lobe epilepsy. J Neurosci 31:2337-2347.

Buckmaster PS, Ingram EA, Wen X (2009) Inhibition of the mammalian target of rapamycin signaling pathway suppresses dentate granule cell axon sprouting in a rodent model of temporal lobe epilepsy. J Neurosci 29:8259-8269.

Cai C, Grabel L (2007) Directing the differentiation of embryonic stem cells to neural stem cells. Dev Dyn 236:3255-3266.

Cai C, Thorne J, Grabel L (2008) Hedgehog serves as a mitogen and survival factor during embryonic stem cell neurogenesis. Stem Cells 26:1097-1108.

Calcagnotto ME, Zipancic I, Piquer-Gil M, Mello LE, Alvarez-Dolado M (2010) Grafting of GABAergic precursors rescues deficits in hippocampal inhibition. Epilepsia 51 [Suppl 3]:66-70.

Campbell K (2003) Dorsal-ventral patterning in the mammalian telencephalon. Curr Opin Neurobiol 13:50-56.

Casarosa S, Fode C, Guillemot F (1999) Mash1 regulates neurogenesis in the ventral telencephalon. Development 126:525-534.

Cecchi C, Boncinelli E (2000) Emx homeogenes and mouse brain development. Trends Neurosci 23:347-352.

Chatzi C, Scott RH, Pu J, Lang B, Nakamoto C, McCaig CD, Shen S (2009) Derivation of homogeneous GABAergic neurons from mouse embryonic stem cells. Exp Neurol 217:407-416.

Chen B, Wang SS, Hattox AM, Rayburn H, Nelson SB, McConnell SK (2008) The Fezf2-Ctip2 genetic pathway regulates the fate choice of subcortical projection neurons in the developing cerebral cortex. Proc Natl Acad Sci U S A 105:11382-11387.

Choi YS, Lin SL, Lee B, Kurup P, Cho HY, Naegele JR, Lombroso PJ, Obrietan K (2007) Status epilepticus-induced somatostatinergic hilar interneuron degeneration is regulated by striatal enriched protein tyrosine phosphatase. J Neurosci 27:2999-3009.

Chu K, Kim M, Jung KH, Jeon D, Lee ST, Kim J, Jeong SW, Kim SU, Lee SK, Shin HS, Roh JK (2004) Human neural stem cell transplantation reduces spontaneous recurrent seizures following pilocarpine-induced status epilepticus in adult rats. Brain Res 1023:213-221.

de Lanerolle NC, Kim JH, Robbins RJ, Spencer DD (1989) Hippocampal interneuron loss and plasticity in human temporal lobe epilepsy. Brain Res 495:387-395. 
Freund TF, Buzsáki G (1996) Interneurons of the hippocampus. Hippocampus 6:347-470.

Freund TF, Gulyás AI (1997) Inhibitory control of GABAergic interneurons in the hippocampus. Can J Physiol Pharmacol 75:479-487.

Galindo LT, Filippo TR, Semedo P, Ariza CB, Moreira CM, Camara NO, Porcionatto MA (2011) Mesenchymal stem cell therapy modulates the inflammatory response in experimental traumatic brain injury. Neurol Res Int 2011:564089.

Germain N, Hartman N, Becker S, Cai C, Naegele JR, Grabel LB (2011) Teratoma formation in embryonic stem cell-derive neural progenitor hippocampal transplants. Cell Transplantation, in press.

Goffin K, Nissinen J, Van Laere K, Pitkänen A (2007) Cyclicity of spontaneous recurrent seizures in pilocarpine model of temporal lobe epilepsy in rat. Exp Neurol 205:501-505.

Guerra L, McGarry LM, Robles V, Bielza C, Larrañaga P, Yuste R (2011) Comparison between supervised and unsupervised classifications of neuronal cell types: a case study. Dev Neurobiol 71:71-82.

Gulyás AI, Hájos N, Freund TF (1996) Interneurons containing calretinin are specialized to control other interneurons in the rat hippocampus. J Neurosci 16:3397-3411.

Haghdoust H, Janahmadi M, Behzadi G (2007) Physiological role of dendrotoxin-sensitive $\mathrm{K}+$ channels in the rat cerebellar Purkinje neurons. Physiol Res 56:807-813.

Halabisky B, Shen F, Huguenard JR, Prince DA (2006) Electrophysiological classification of somatostatin-positive interneurons in mouse sensorimotor cortex. J Neurophysiol 96:834-845.

Hartman NW, Carpentino JE, LaMonica K, Mor DE, Naegele JR, Grabel L (2010) CXCL12-mediated guidance of migrating embryonic stem cellderived neural progenitors transplanted into the hippocampus. PLoS One 5:e15856.

Houser CR, Esclapez M (1994) Localization of mRNAs encoding two forms of glutamic acid decarboxylase in the rat hippocampal formation. Hippocampus 4:530-545.

Houser CR, Esclapez M (1996) Vulnerability and plasticity of the GABA system in the pilocarpine model of spontaneous recurrent seizures. Epilepsy Res 26:207-218.

Jäderstad J, Jäderstad LM, Li J, Chintawar S, Salto C, Pandolfo M, Ourednik V, Teng YD, Sidman RL, Arenas E, Snyder EY, Herlenius E (2010) Communication via gap junctions underlies early functional and beneficial interactions between grafted neural stem cells and the host. Proc Natl Acad Sci U S A 107:5184-5189.

Jonas P, Bischofberger J, Fricker D, Miles R (2004) Interneuron Diversity series: Fast in, fast out-temporal and spatial signal processing in hippocampal interneurons. Trends Neurosci 27:30-40.

Katsumaru H, Kosaka T, Heizmann CW, Hama K (1988) Immunocytochemical study of GABAergic neurons containing the calcium-binding protein parvalbumin in the rat hippocampus. Exp Brain Res 72:347-362.

Kawaguchi Y, Katsumaru H, Kosaka T, Heizmann CW, Hama K (1987) Fast spiking cells in rat hippocampus (CAl region) contain the calciumbinding protein parvalbumin. Brain Res 416:369-374.

Kim SU, de Vellis J (2009) Stem cell-based cell therapy in neurological diseases: a review. J Neurosci Res 87:2183-2200.

Kokate TG, Cohen AL, Karp E, Rogawski MA (1996) Neuroactive steroids protect against pilocarpine- and kainic acid-induced limbic seizures and status epilepticus in mice. Neuropharmacology 35:1049-1056.

Lacaille JC, Williams S (1990) Membrane properties of interneurons in stratum oriens-alveus of the CA1 region of rat hippocampus in vitro. Neuroscience 36:349-359.

Leid M, Ishmael JE, Avram D, Shepherd D, Fraulob V, Dollé P (2004) CTIP1 and CTIP2 are differentially expressed during mouse embryogenesis. Gene Expr Patterns 4:733-739.

Li XJ, Zhang X, Johnson MA, Wang ZB, Lavaute T, Zhang SC (2009) Coordination of sonic hedgehog and Wnt signaling determines ventral and dorsal telencephalic neuron types from human embryonic stem cells. Development 136:4055-4063.

Liu S, Wang J, Zhu D, Fu Y, Lukowiak K, Lu YM (2003) Generation of functional inhibitory neurons in the adult rat hippocampus. J Neurosci 23:732-736.

Lübke J, Frotscher M, Spruston N (1998) Specialized electrophysiological properties of anatomically identified neurons in the hilar region of the rat fascia dentata. J Neurophysiol 79:1518-1534.

Maccaferri G, McBain CJ (1996) The hyperpolarization-activated current
(Ih) and its contribution to pacemaker activity in rat CA1 hippocampal stratum oriens-alveus interneurones. J Physiol 497:119-130.

Maisano X, Carpentino J, Becker S, Lanza R, Aaron G, Grabel L, Naegele JR (2009) Embryonic stem cell-derived neural precursor grafts for treatment of temporal lobe epilepsy. Neurotherapeutics 6:263-277.

Marchi N, Oby E, Batra A, Uva L, De Curtis M, Hernandez N, Van BoxelDezaire A, Najm I, Janigro D (2007) In vivo and in vitro effects of pilocarpine: relevance to ictogenesis. Epilepsia 48:1934-1946.

Marchi N, Fan Q, Ghosh C, Fazio V, Bertolini F, Betto G, Batra A, Carlton E, Najm I, Granata T, Janigro D (2009) Antagonism of peripheral inflammation reduces the severity of status epilepticus. Neurobiol Dis 33:171-181.

Margerison JH, Corsellis JA (1966) Epilepsy and the temporal lobes. A clinical, electroencephalographic and neuropathological study of the brain in epilepsy, with particular reference to the temporal lobes. Brain 89:499-530.

Maroof AM, Brown K, Shi SH, Studer L, Anderson SA (2010) Prospective isolation of cortical interneuron precursors from mouse embryonic stem cells. J Neurosci 30:4667-4675.

McGarry LM, Packer AM, Fino E, Nikolenko V, Sippy T, Yuste R (2010) Quantitative classification of somatostatin-positive neocortical interneurons identifies three interneuron subtypes. Front Neural Circuits 4:12.

Miyoshi G, Butt SJ, Takebayashi H, Fishell G (2007) Physiologically distinct temporal cohorts of cortical interneurons arise from telencephalic Olig2expressing precursors. J Neurosci 27:7786-7798.

Molnár Z, Cheung AF (2006) Towards the classification of subpopulations of layer V pyramidal projection neurons. Neurosci Res 55:105-115.

Naegele JR, Maisano X, Yang J, Royston S, Ribeiro E (2010) Recent advancements in stem cell and gene therapies for neurological disorders and intractable epilepsy. Neuropharmacology 58:855-864.

Nelson SB, Sugino K, Hempel CM (2006) The problem of neuronal cell types: a physiological genomics approach. Trends Neurosci 29:339-345.

Obenaus A, Esclapez M, Houser CR (1993) Loss of glutamate decarboxylase mRNA-containing neurons in the rat dentate gyrus following pilocarpine-induced seizures. J Neurosci 13:4470-4485.

Oliva AA Jr, Jiang M, Lam T, Smith KL, Swann JW (2000) Novel hippocampal interneuronal subtypes identified using transgenic mice that express green fluorescent protein in GABAergic interneurons. J Neurosci 20:3354-3368.

Pavlov I, Scimemi A, Savtchenko L, Kullmann DM, Walker MC (2011) I(h)mediated depolarization enhances the temporal precision of neuronal integration. Nat Commun 2:199.

Rafiq A, DeLorenzo RJ, Coulter DA (1993) Generation and propagation of epileptiform discharges in a combined entorhinal cortex/hippocampal slice. J Neurophysiol 70:1962-1974.

Robbins RJ, Brines ML, Kim JH, Adrian T, de Lanerolle N, Welsh S, Spencer DD (1991) A selective loss of somatostatin in the hippocampus of patients with temporal lobe epilepsy. Ann Neurol 29:325-332.

Robinson RB, Siegelbaum SA (2003) Hyperpolarization-activated cation currents: from molecules to physiological function. Annu Rev Physiol 65:453-480.

Ruschenschmidt C, Koch PG, Brustle O, Beck H (2005) Functional properties of ES cell-derived neurons engrafted into the hippocampus of adult normal and chronically epileptic rats. Epilepsia 46 [Suppl 5]:174-183.

Seminatore C, Polentes J, Ellman D, Kozubenko N, Itier V, Tine S, Tritschler L, Brenot M, Guidou E, Blondeau J, Lhuillier M, Bugi A, Aubry L, Jendelova P, Sykova E, Perrier AL, Finsen B, Onteniente B (2010) The postischemic environment differentially impacts teratoma or tumor formation after transplantation of human embryonic stem cellderived neural progenitors. Stroke 41:153-159.

Shibley H, Smith BN (2002) Pilocarpine-induced status epilepticus results in mossy fiber sprouting and spontaneous seizures in C57BL/6 and CD-1 mice. Epilepsy Res 49:109-120.

Sik A, Penttonen M, Ylinen A, Buzsáki G (1995) Hippocampal CA1 interneurons: an in vivo intracellular labeling study. J Neurosci 15:6651-6665.

Silva A, Pereira J, Oliveira CR, Relvas JB, Rego AC (2009) BDNF and extracellular matrix regulate differentiation of mice neurosphere-derived cells into a GABAergic neuronal phenotype. J Neurosci Res 87:1986-1996.

Sousa VH, Fishell G (2010) Sonic hedgehog functions through dynamic changes in temporal competence in the developing forebrain. Curr Opin Genet Dev 20:391-399.

Sugino K, Hempel CM, Miller MN, Hattox AM, Shapiro P, Wu C, Huang ZJ, 
Nelson SB (2006) Molecular taxonomy of major neuronal classes in the adult mouse forebrain. Nat Neurosci 9:99-107.

Swartz BE, Houser CR, Tomiyasu U, Walsh GO, DeSalles A, Rich JR, Delgado-Escueta A (2006) Hippocampal cell loss in posttraumatic human epilepsy. Epilepsia 47:1373-1382.

Szabadics J, Varga C, Brunner J, Chen K, Soltesz I (2010) Granule cells in the CA3 area. J Neurosci 30:8296-8307.

Thind KK, Yamawaki R, Phanwar I, Zhang G, Wen X, Buckmaster PS (2010) Initial loss but later excess of GABAergic synapses with dentate granule cells in a rat model of temporal lobe epilepsy. J Comp Neurol 518:647-667.

Tóth K, Eross L, Vajda J, Halász P, Freund TF, Maglóczky Z (2010) Loss and reorganization of calretinin-containing interneurons in the epileptic human hippocampus. Brain 133:2763-2777.

Vezzani A, Granata T (2005) Brain inflammation in epilepsy: experimental and clinical evidence. Epilepsia 46:1724-1743.

Vezzani A, Peltola J, Janigro D (2008) Inflammation. Philadelphia: Lippincott Williams and Wilkins.

Waldau B, Hattiangady B, Kuruba R, Shetty AK (2010) Medial ganglionic eminence-derived neural stem cell grafts ease spontaneous seizures and restore GDNF expression in a rat model of chronic temporal lobe epilepsy. Stem Cells 28:1153-1164.

Watanabe K, Kamiya D, Nishiyama A, Katayama T, Nozaki S, Kawasaki H, Watanabe Y, Mizuseki K, Sasai Y (2005) Directed differentiation of telencephalic precursors from embryonic stem cells. Nat Neurosci 8:288-296.

Wenzel HJ, Cole TB, Born DE, Schwartzkroin PA, Palmiter RD (1997) Ultrastructural localization of zinc transporter-3 (ZnT-3) to synaptic vesicle membranes within mossy fiber boutons in the hippocampus of mouse and monkey. Proc Natl Acad Sci U S A 94:12676-12681.
Wernig M, Benninger F, Schmandt T, Rade M, Tucker KL, Büssow H, Beck H, Brüstle O (2004) Functional integration of embryonic stem cell-derived neurons in vivo. J Neurosci 24:5258-5268.

Wittner L, Eross L, Szabó Z, Tóth S, Czirják S, Halasz P, Freund TF, Maglóczky ZS (2002) Synaptic reorganization of calbindin-positive neurons in the human hippocampal CA1 region in temporal lobe epilepsy. Neuroscience 115:961-978.

Xiong N, Cao X, Zhang Z, Huang J, Chen C, Zhang Z, Jia M, Xiong J, Liang Z, Sun S, Lin Z, Wang T (2010) Long-term efficacy and safety of human umbilical cord mesenchymal stromal cells in rotenone-induced hemiparkinsonian rats. Biol Blood Marrow Transplant 16:1519-1529.

Xu Q, Cobos I, De La Cruz E, Rubenstein JL, Anderson SA (2004) Origins of cortical interneuron subtypes. J Neurosci 24:2612-2622.

Xu Q, Guo L, Moore H, Waclaw RR, Campbell K, Anderson SA (2010) Sonic hedgehog signaling confers ventral telencephalic progenitors with distinct cortical interneuron fates. Neuron 65:328-340.

Ying QL, Smith AG (2003) Defined conditions for neural commitment and differentiation. Methods Enzymol 365:327-341.

Zhang W, Buckmaster PS (2009) Dysfunction of the dentate basket cell circuit in a rat model of temporal lobe epilepsy. J Neurosci 29:7846-7856.

Zhang W, Yamawaki R, Wen X, Uhl J, Diaz J, Prince DA, Buckmaster PS (2009) Surviving hilar somatostatin interneurons enlarge, sprout axons, and form new synapses with granule cells in a mouse model of temporal lobe epilepsy. J Neurosci 29:14247-14256.

Zipancic I, Calcagnotto ME, Piquer-Gil M, Mello LE, Alvarez-Dolado M (2010) Transplant of GABAergic precursors restores hippocampal inhibitory function in a mouse model of seizure susceptibility. Cell Transplant 19:549-564. 